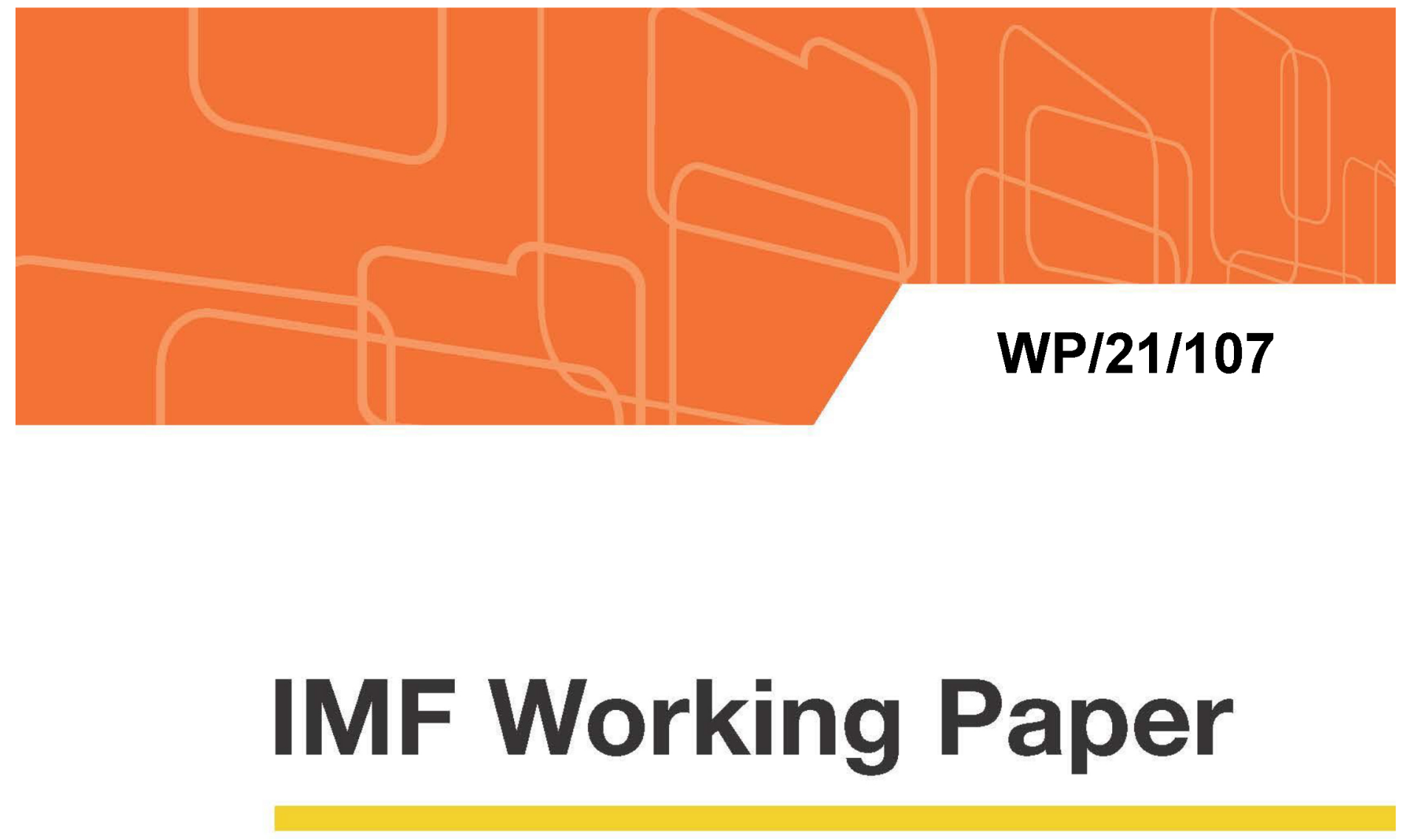

\title{
Impact of Interest Rate Cap on Financial Inclusion in Cambodia
}

by Dyna Heng, Serey Chea, and Bomakara Heng

IMF Working Papers describe research in progress by the author(s) and are published to elicit comments and to encourage debate. The views expressed in IMF Working Papers are those of the author(s) and do not necessarily represent the views of the IMF, its Executive Board, or IMF management.

$$
\text { I N T E R N A T I O N A L M O N E T A R Y F U N D }
$$




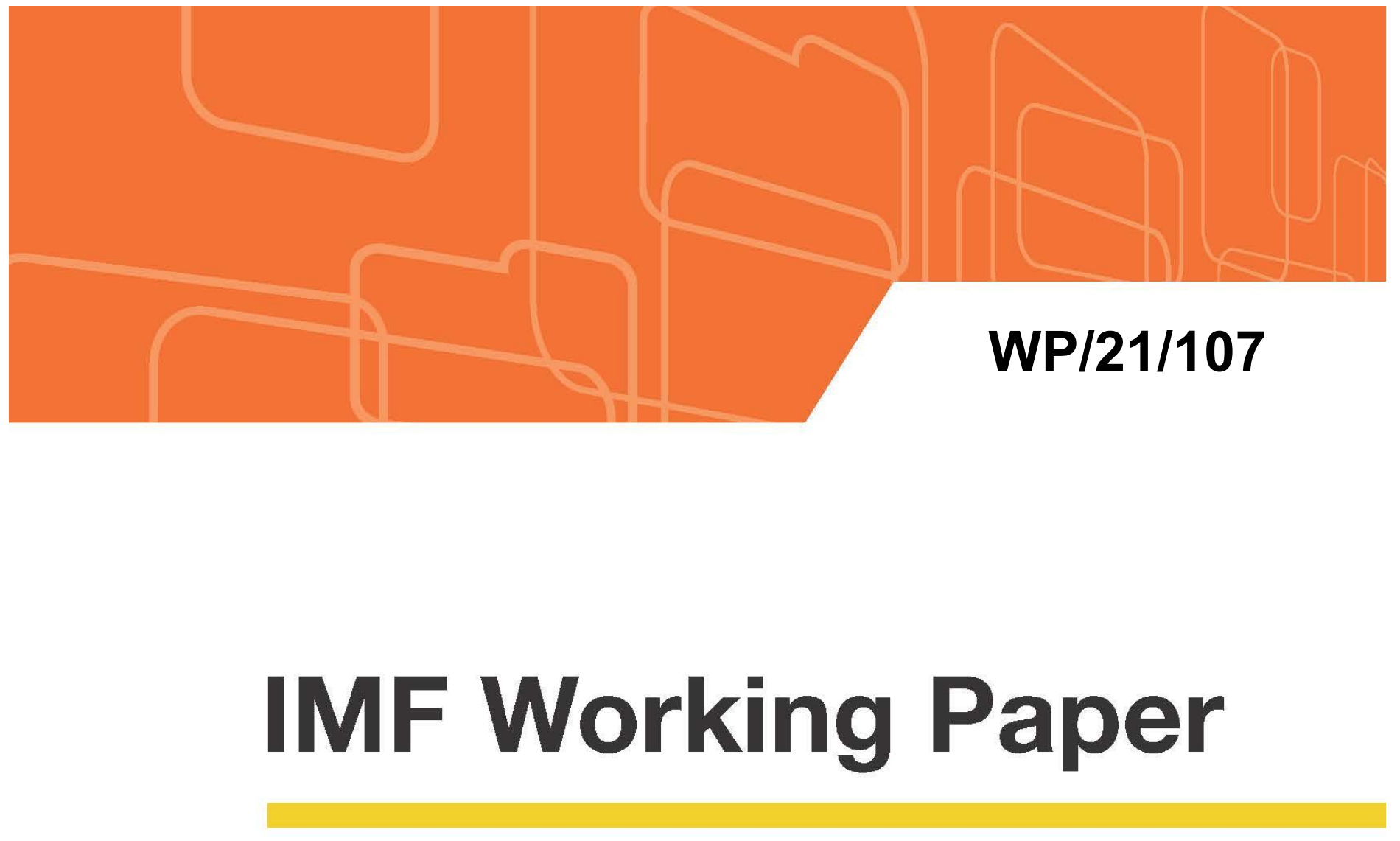

\section{Impact of Interest Rate Cap on Financial Inclusion in Cambodia}

by Dyna Heng, Serey Chea, and Bomakara Heng

IMF Working Papers describe research in progress by the author(s) and are published to elicit comments and to encourage debate. The views expressed in IMF Working Papers are those of the author(s) and do not necessarily represent the views of the IMF, its Executive Board, or IMF management.

$$
\text { I N T E R N A T | O N A L M O N E T A R Y F U N D }
$$




\title{
IMF Working Paper
}

Institute of Capacity Development

\section{Impact of Interest Rate Cap on Financial Inclusion in Cambodia \\ Prepared by Dyna Heng, Serey Chea, and Bomakara Heng ${ }^{1}$}

Authorized for distribution by Paul Cashin

April 2021

\section{IMF Working Papers describe research in progress by the author(s) and are published to elicit comments and to encourage debate. The views expressed in IMF Working Papers are those of the author(s) and do not necessarily represent the views of the IMF, its Executive Board, or IMF management.}

\begin{abstract}
Interest rate caps, despite their intended objective of broadening financial inclusion, can have undesirable effects on financial inclusion under certain conditions. This paper examines the effect of microfinance-loan interest rate caps on financial inclusion in Cambodia. Based on a difference-in-difference analysis on bank and microfinance supervisory data, results show some unintended impact on financial inclusion. The cap led to a significant increase in non-interest fees charged on new loans following the introduction of an annual cap. Microfinance borrowers declined immediately, amid an increase in credit growth, as microfinance institutions targeted larger borrowers at the expense of smaller ones. Microfinance institutions, responded differently to the cap, considering their own operation and funding costs, and client base. Two years after the cap, institutions resumed lending to a wider group of borrowers with lower funding and operation costs brought by mobile payment development.
\end{abstract}

JEL Classification Numbers: G18, G21, G28

Keywords: Financial Inclusion, Interest Rate Caps, Banking Sector

\footnotetext{
${ }^{1}$ The authors would like to thank Laura Kodres, Paul Cashin, Philippe Karam, Vassili Prokopenko, Hui He, Marco Pani and participants at the IMF ICD departmental seminar for valuable inputs and feedback at various stages of the research. Mr. Virak Khem at the National Bank of Cambodia has been helpful in providing data support.
} 
Authors’ E-Mail Address: dheng@imf.org; cheaserey@nbc.org.kh; hbomakara@nbc.org.kh

\section{Contents}

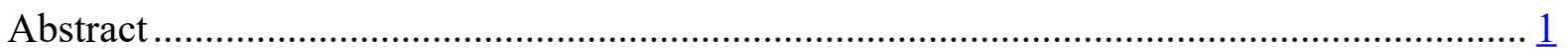

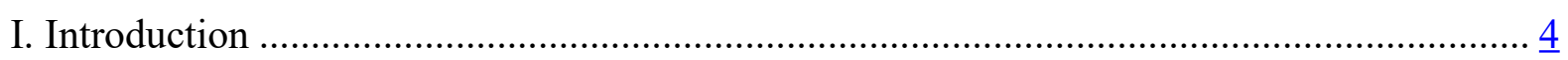

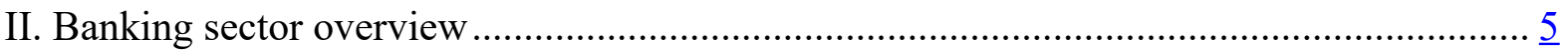

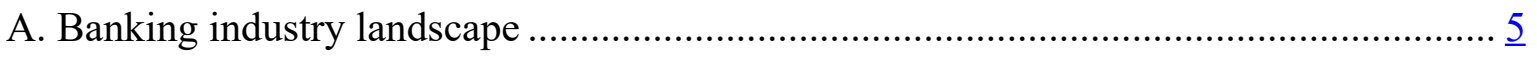

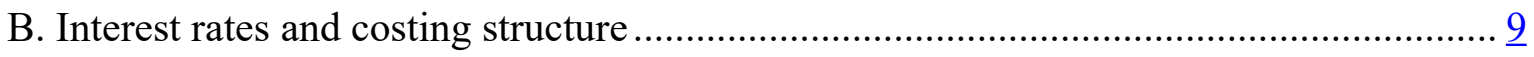

III. The Interest rate cap: Purpose and design........................................................... 15

IV. Impact of the interest rate cap in Cambodia ........................................................... 16

V. Empirical assessment ..................................................................................... 22

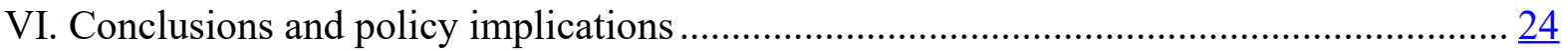

Appendix 1: Cross-country experience: Interest rate caps and financial inclusion ........ 28

Appendix 2: Structural break of key variables among MDIs and MFIs....................... $\underline{30}$

Appendix 3: Prudential regulation comparison between CBs and MDIs (MFIs)........... $\underline{32}$

Appendix 4: Regulation on the interest rate, March 2017 ......................................... 33 


$\begin{array}{ll}\text { Abbrieviation } & \\ \text { ABC } & \text { Association of Banks in Cambodia } \\ \text { CBC } & \text { Credit Bureau of Cambodia } \\ \text { DTI } & \text { Debt to Income } \\ \text { LTV } & \text { Loan to Value } \\ \text { MFIs } & \text { Microfinance Institutions (non-deposit taking) } \\ \text { MDIs } & \text { Microfinance Deposit-taking Institutions } \\ \text { NBC } & \text { National Bank of Cambodia } \\ \text { NGOs } & \text { Non-Governmental Organizations }\end{array}$




\section{INTRODUCTION}

Cambodia has one of the fastest-growing microfinance sectors in Asia. Microfinance institutions increased tenfold from 7 in 2004 to 82 in 2019, and the number of borrowers has doubled to 2.1 million between 2010 and 2019. The sector, however, has faced several challenges including significant reliance on foreign financing, high costs of funding, concerns of over-indebtedness, and low financial literacy among borrowers.

In March 2017, the National Bank of Cambodia (NBC) introduced an 18 percent cap on annual interest rate of microfinance loans both denominated in local currency and US dollars. The cap was intended to alleviate borrowers' repayment burden and further improve efficiency of the microfinance sector. The ceiling was imposed after a prolonged period of concerns on excessive interest rate which could undermine the poverty-reduction purpose and sustained healthy development of the microfinance sector. There had also been public campaigns by the government to clarify that microfinance institutions are not affiliated with government institutions. ${ }^{2}$

Has the cap been effective in achieving its objectives, or has it been largely circumvented, with negative consequences? Using a difference-in-difference approach on banks and nonbank, microfinance supervisory data, this paper examines the short and medium-term effect of the interest rate cap on the microfinance sector and financial inclusion. The analysis uses data at both financial-institution level and aggregate level from end-2016 to end-2019. The timeframe is chosen so that we can observe the short and medium-term dynamics after the cap was imposed, prior to the Covid-19 pandemic.

Our analysis shows that after the cap was introduced, microfinance institutions turned to charge higher non-interest rate fees to offset the interest income loss. Loan-related commission fees have tripled, on average across all microfinance institutions. In addition, the number of borrowers declined immediately after the cap was introduced but total microfinance loans continued to grow. Some microfinance institutions have turned away from small borrowers and shifted toward larger ones. The impact of the cap on the number of borrowers has varied across financial institutions, depending on operation costs, funding costs, and segment of clients served. Microfinance institutions providing larger loans to urban areas tend to be less affected. Moreover, data suggests that microfinance secured lower funding costs and reduced operation costs by adopting a mobile payment network.

Going forward, if the interest rate cap intended to protect borrowers from usury rates is upheld, it would need to be adjusted to reflect market conditions. Enforcing the cap in a way that is inconsistent with market conditions, risks reversing the financial inclusion efforts to date, and creates incentives for unregulated entities to emerge and grow. This would transfer the problems out of the domain of regulators.

\footnotetext{
2 The concern was also voiced by the by the Prime Minister and the Minister of Defense. Phnom Penh Post, 2017. "MFI Loan Interest Capped”, 14 March 2017. https://www.phnompenhpost.com/national/mfi-loaninterest-capped.
} 
There are several policy alternatives to the interest rate cap that can help protect borrowers from excessive interest rates and limit the negative impact of the cap. Policy options include enhancing the borrower protection framework, fostering healthy competition, and promoting efficiency of the microfinance industry. Encouraging orderly consolidation of the microfinance industry may also help improve efficiency by reducing overhead costs and operation expenses.

To our knowledge, this paper is the first to use difference-in-difference approach on supervisory data to examine the impact of interest rate on financial inclusion, with few empirical studies providing evidence of the impact of interest rate caps (see Maimbo and Gallegos, 2014). In many countries, identifying the causal impact of interest rate cap has been challenging because of a lack of data, the interest rate cap being applied on all financial institutions in those countries, and contemporaneous events such as elections or economic shocks. The nature of the interest rate cap in Cambodia is a good setup for the chosen empirical approach as the cap is applied to microfinance institutions only, but not to other key lenders such as banks, many of which compete actively with microfinance institutions.

The paper is structured as follows. Section II gives a brief overview of financial institutions in Cambodia prior to the cap. Section III highlights the purpose and design of the interest rate cap. Section IV discusses key changes in the financial landscape after the cap was introduced. Section $\mathrm{V}$ provides an empirical assessment on the impact of the interest rate cap. Section VI concludes and discusses policy options to achieve the objectives of the NBC and the government.

\section{BANKING SECTOR OVERVIEW}

Banking industry landscape, cost structure, and performance

A. Banking industry landscape

When the cap was introduced in March 2017, Cambodia's financial system consisted of 39 commercial banks, 15 specialized banks, 76 microfinance institutions, and 313 rural credit operators (Figure 1). Out of 76 microfinance institutions, 69 are non-deposit microfinance institutions (MFIs) and 7 are deposit-taking microfinance institutions (MDIs) which basically operates similar to commercial banks.

The microfinance sector in Cambodia is dominated by seven MDIs which account for 84 percent of the total assets. In terms of asset size, number of borrowers, and loan outstanding, some MDIs are even bigger than some commercial banks. Overall, the microfinance industry accounts for 26 percent of the total loans portfolio of the whole banking industry and captures 68 percent of the total borrowers ${ }^{3}$ (Figure 2). This number reflects the growing

\footnotetext{
${ }^{3}$ This number excludes the rural credit operators which are very small players in the market.
} 
systemic importance of the microfinance industry in terms of the volume of the customers served. Pawnshop and informal lenders have also been actively engaged in providing loans ${ }^{4}$.
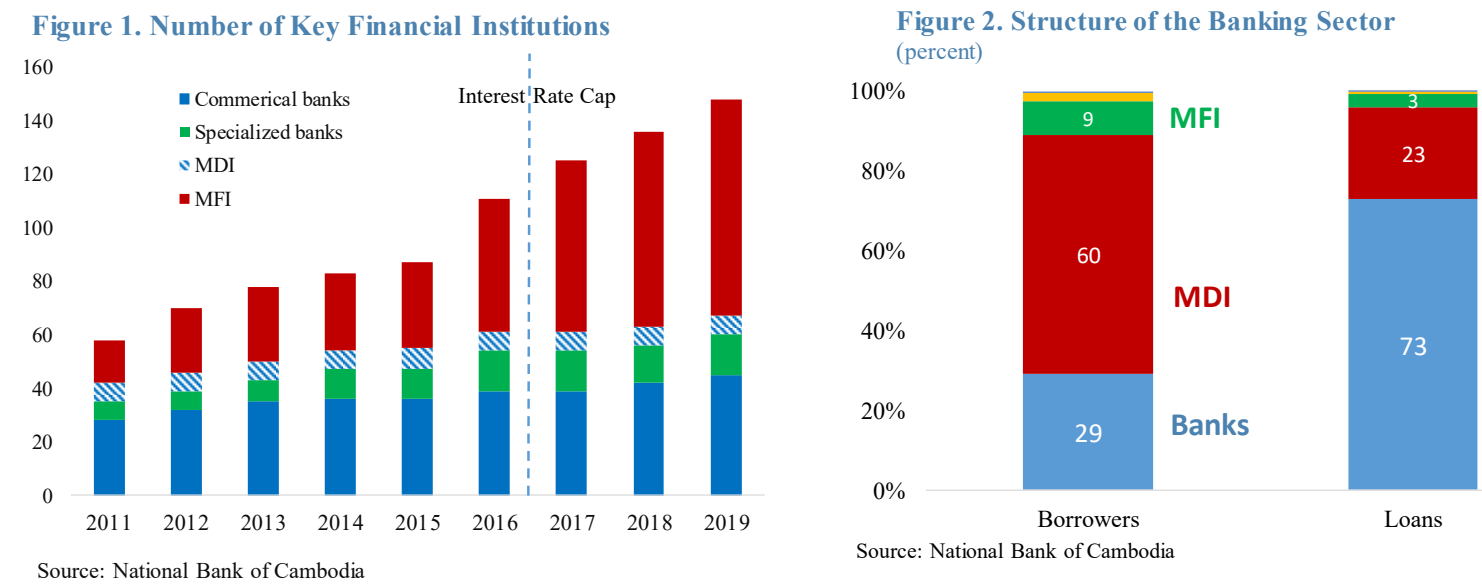

The microfinance industry in Cambodia expanded significantly from just 3 million USD of total loans ( 0.12 percent of GDP) and 50,000 borrowers in 1992 to about 1 billion USD and 1.2 million borrowers in 2012, and then to 3 billion USD (15 percent of GDP) and 1.9 million borrowers in 2017 (Figure 3). Amid rapid economic growth over the past two decades, microfinance industry has increasingly contributed to domestic credit growth which has been about 30 percent every year (Figure 4). Total credit to GDP provided by banks and microfinance increased from 24 percent in 2009 to around 105 percent in 2017.
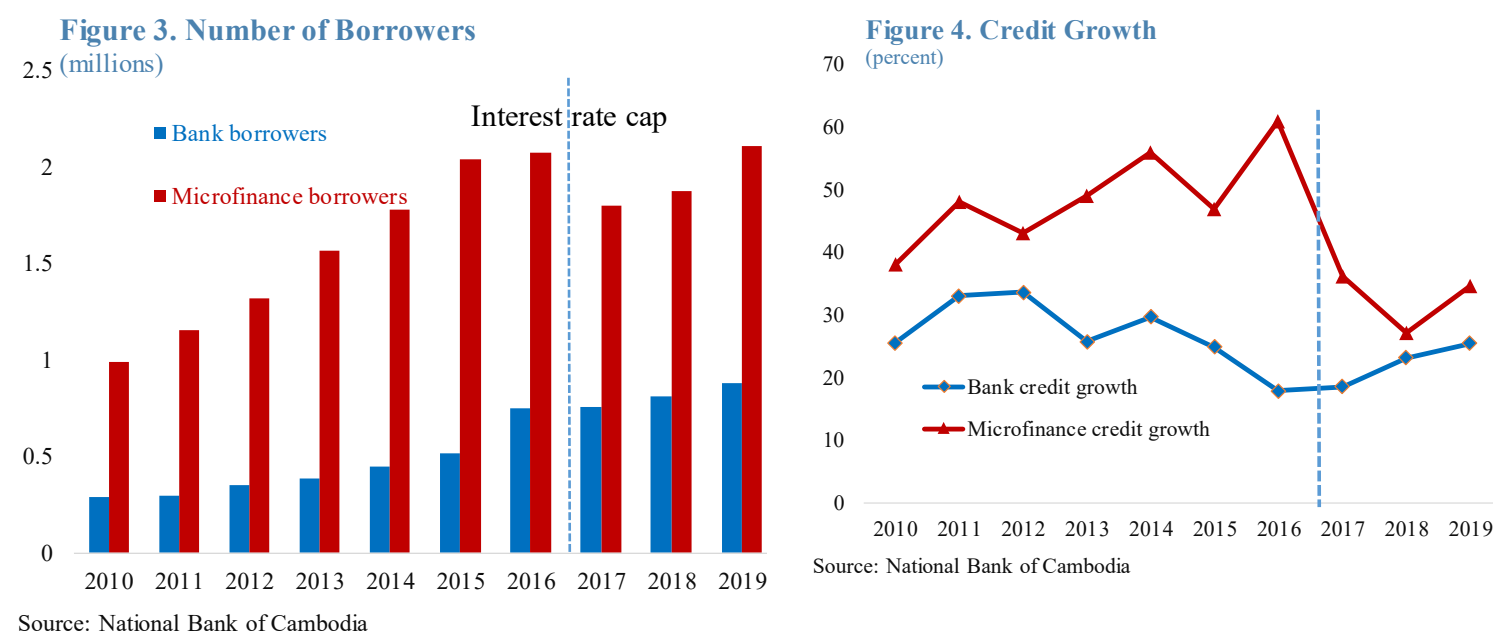

Growing from a mostly social oriented non-governmental organizations (NGOs), the microfinance industry has played an important role in increasing access to finance and contributed to improve living conditions in rural areas. Thanks to the regulatory framework

\footnotetext{
${ }^{4}$ Pawnshops are regulated by the Ministry of Economy and Finance, while banks and microfinance institutions are regulated by National Bank of Cambodia. The cap is not applied to pawnshops.
} 
that promotes transparency ${ }^{5}$, low non-performing loans, and high profitability ${ }^{6}$ (Figures 5 and 6 ), private sector's interests in the industry grew, significantly expanding the total number of microfinance institutions and their outreach, with over 1000 branches countrywide, often in locations unattractive to conventional banking institutions. In 2000, upon the promulgation of the Law on Banking and Financial Institutions, Cambodia was amongst the first countries in the world to regulate its microfinance industry. In 2010, the Economist Intelligence Unit Global Microscope ranked Cambodia number one for having the most conducive regulatory framework for microfinance industry in the world (EIU 2013).
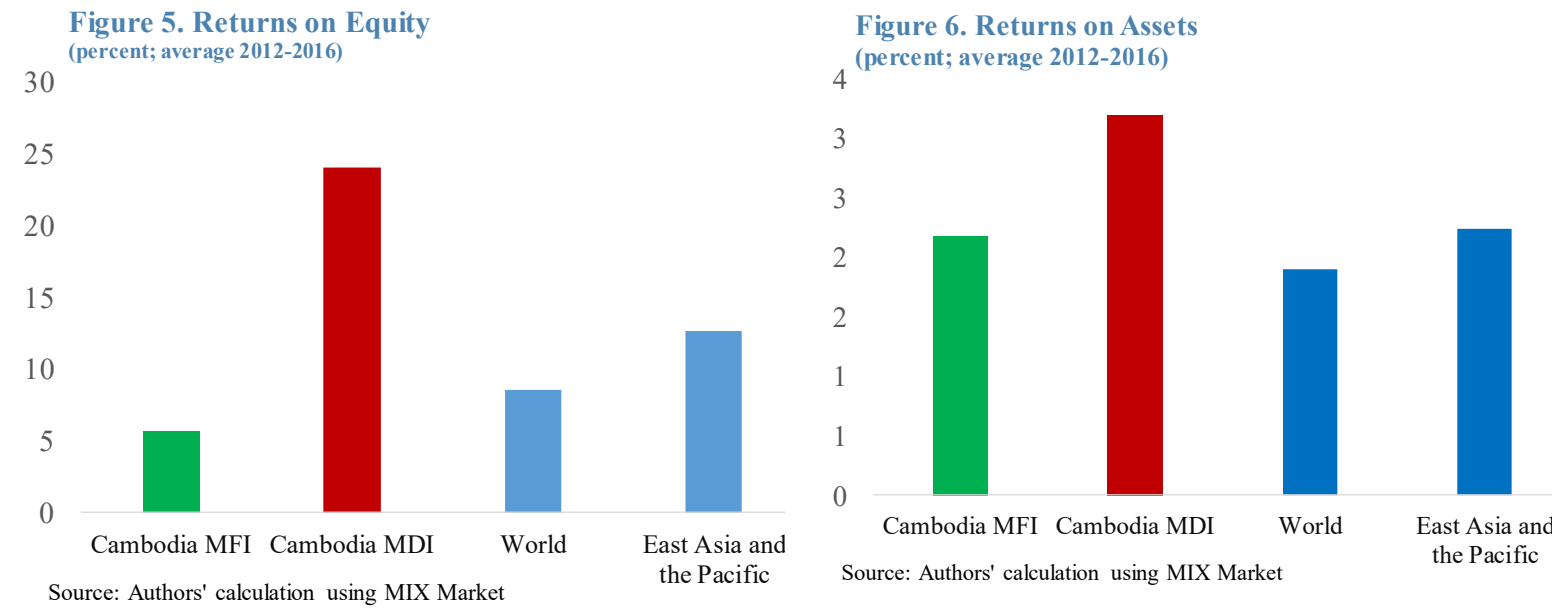

Realizing the constraints of the microfinance institutions to (i) provide a safe place to save to people in rural areas with no access to bank branches, (ii) increasing reliance on foreign funding that can expose the industry to external shocks as experienced during the global financial crisis ${ }^{7}$, (iii) high costs of funding, and (iv) increasing currency mismatch in their portfolio because of their inability to raise local currency funding, the NBC introduced a regulation in 2009 that allowed qualified microfinance institutions to collect deposits from the public while at the same time subjecting them to stricter regulatory requirements than non-deposit-taking microfinance institutions. Microfinance Deposit-Taking Institutions (MDIs) category emerged and eventually played an important role in the microfinance industry and access to finance in Cambodia ${ }^{8}$. Regulations and supervisions of microfinance

\footnotetext{
${ }^{5}$ Microfinance institutions are required to publish their annual audited reports.

${ }^{6}$ The high returns on assets (largely loans) between 2012-2016 had been driven by rapid expansion of microfinance borrower base, high interest rates, and low default rates.

${ }^{7}$ In 2008, microfinance sector was the most hit by the global financial crisis, particularly in term of their funding, as most funders were themselves affected and pre-agreed fund release had to be halted.

${ }^{8}$ For the purpose of this paper, microfinance institutions include MDIs (deposit-taking institutions) and MFIs (non-deposit taking institutions).
} 
institutions are tiered depending on the degree of risks posed to the financial system stability (Appendix 3 compares the prudential regulations on banks and MDIs). ${ }^{9}$

Microfinance institutions in Cambodia can be grouped into three categories. Figure 7 and 8 show the variations in average loan sizes and number of borrowers among microfinance institutions.

- $\quad$ Group I: These microfinance institutions (mostly MDIs and few others MFIs) serve mostly small and medium enterprises and provide relatively larger loans mainly in USD dollars. The average loan per client in this group is usually above $2000 \mathrm{USD}^{10}$. These microfinance institutions tend to have relatively lower operation costs as they, like banks, have clients come to their office for loan disbursement and collection.

- $\quad$ Group II: Microfinance institutions (mostly MFIs) in this group provide small loans and group lending. They are willing to take more risks providing loans with less documentation requirement, accepting soft title deeds and other forms of personal guarantees as collaterals. These microfinance institutions also provide smaller loans to individual in local currency (Riels). The average loan size is normally less than 500 USD. Unlike banks and Group I, these microfinance institutions disburse loans and collect payments at the village, and thus generally have higher operation costs.

However, from borrower perspective, they would still choose the services as it is still better than travelling long distance just to pay small payment every month.

- $\quad$ Group III: These microfinance institutions provide both small loans and larger loans to SMEs.

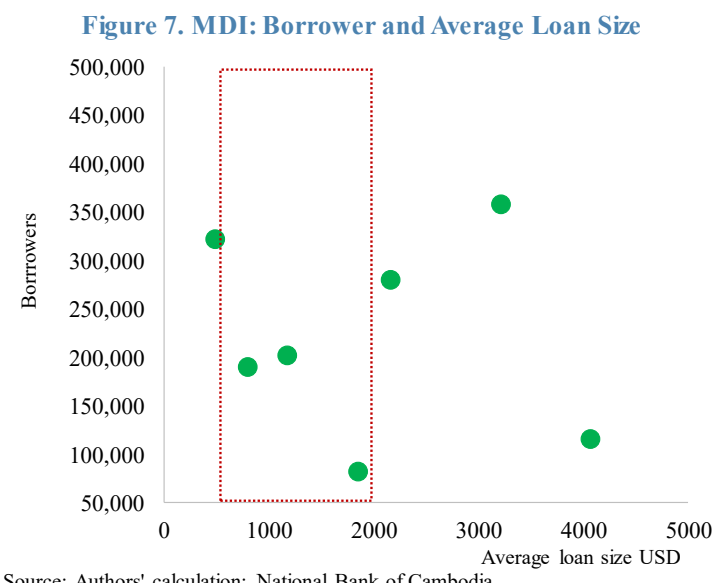

Source: Authors' calculation; National Bank of Cambodia

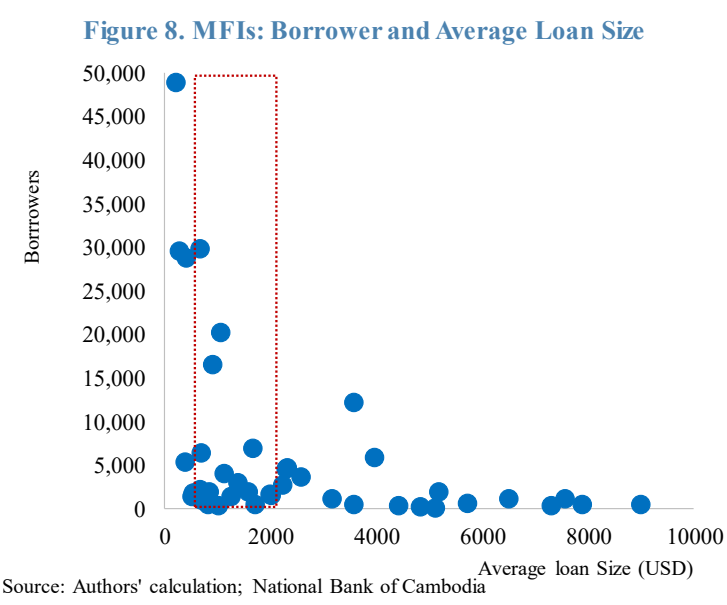

Source: Authors' calculation; National Bank of Cambodia

\footnotetext{
${ }^{9}$ Large financial institutions are subject to stricter regulation and supervision. A comparison of prudential regulation between banks and microfinance institutions are provided in Appendix I.

${ }^{10}$ Cambodia's GDP per capita is about 1300 USD in 2018.
} 
B. Interest rates and costing structure

Compared to banks, microfinance institutions tend to charge higher interest rate due to higher funding costs, have higher operation costs, and, for MFIs, face higher credit risks associated with small borrowers. At end-2016 before the cap was introduced, the top ten microfinance institutions, which capture about 90 percent of the market, charged an average rate of 28 percent compared with banks average lending rate of 12 percent in USD and 21 percent in KHR. Microfinance loan interest rates vary between 15 and 36 percent, depending on currency denomination (local versus US dollar), loan size, and credit risks of borrowers. Reflecting this higher-risk-higher-return profile, the interest income as a percentage of total loans among microfinance institutions are well above that of commercial banks (Figure 9). Informal lenders, in contrast, can charge over 100 percent per year often with predatory terms and conditions. There have been anecdotes and news reporting that lenders required borrowers to sign a Sale and Purchase Agreement of their collaterals with lenders. This practice is against the law in Cambodia and often leads to unethical foreclosure practice.

Moreover, small loans and group lending face higher risks as loans are normally unsecured. Different from banks, microfinance institutions provide small loans to households and smallscale enterprises with more simplified loan documentation, credit risk analysis, and softcollateral ${ }^{11}$. Small loans in rural areas are often linked to agriculture that relies largely on unpredictable weather conditions (flood and drought). NPL rate among MFIsis 3 times higher than that of commercial banks, on average, explaining losses among several MFIs.

Most microfinance institutions tend to have higher operation and funding costs than banks. Figure 10 shows a breakdown of loan cost comparison between banks and microfinance institutions. In general, microfinance institutions tend to have higher administrative (overhead) costs, high funding costs due to foreign funding, and higher risk loans (group lending and small loans with few document requirements). Nonetheless, costs of loans vary by institutions with significantly higher costs for smaller microfinance institutions which are well above the 18 percent cap (Figures 11 and 12).

\footnotetext{
${ }^{11}$ While banks normally require "hard tittle", national level-certificate of property ownership, most microfinance loans are collateralized with "soft title", a village/district level-certificate of ownership.
} 

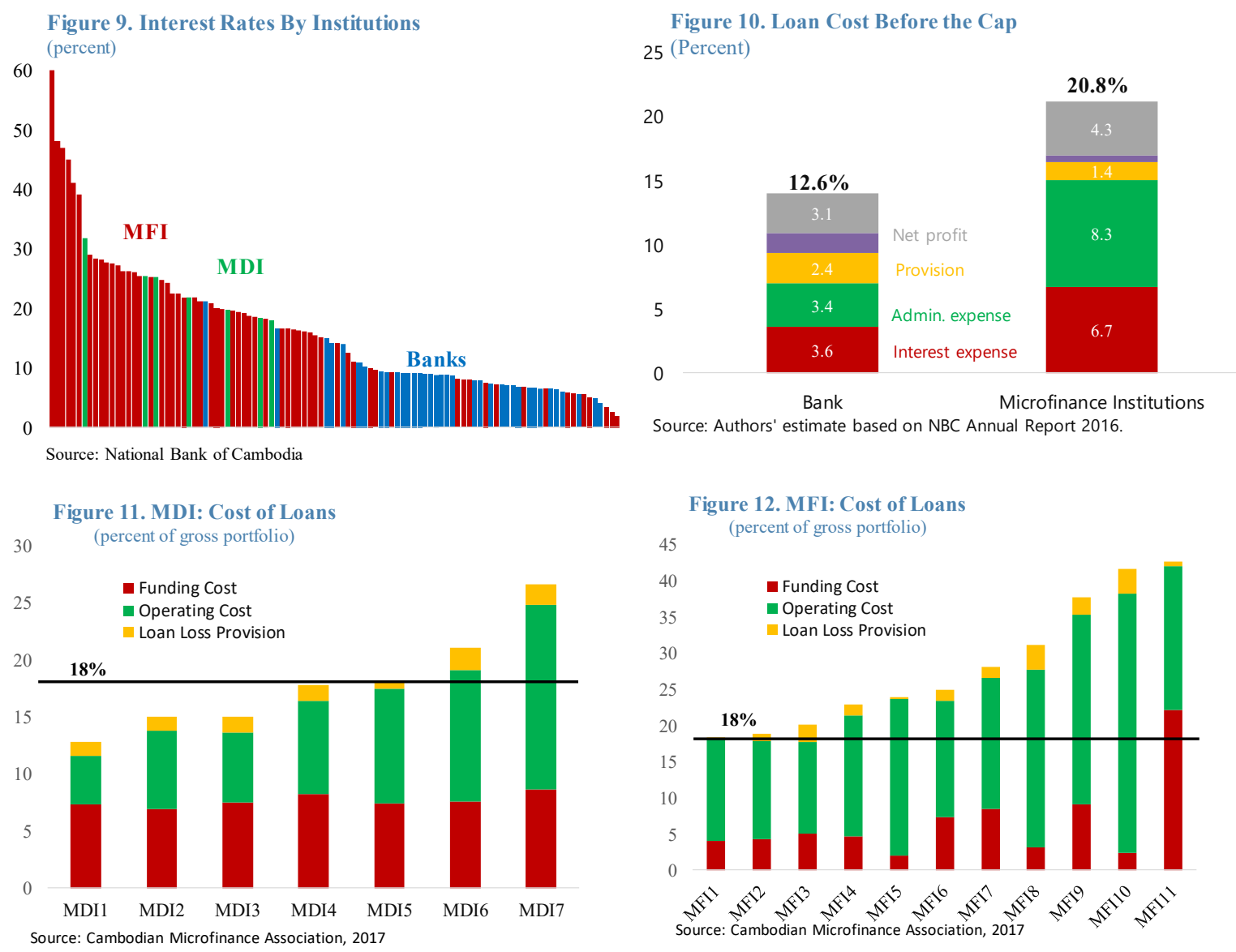

\section{Operation costs}

Microfinance industry in Cambodia remains a cost intensive industry, with operation costs accounting for 43 percent of total expense ${ }^{12}$. Figure 13 shows the stark difference between operation costs of microfinance institutions and of banks. Small MFIs have even higher operation costs. Unlike banks that disburse mostly large loans to well documented customers, microfinance institutions are dealing with low income individuals and small and medium enterprises who lack proper documentation and collaterals. In order to serve this perceived high-risk segment of the markets, microfinance institutions rely on credit officers to do due diligent on site and go for regular visit to the

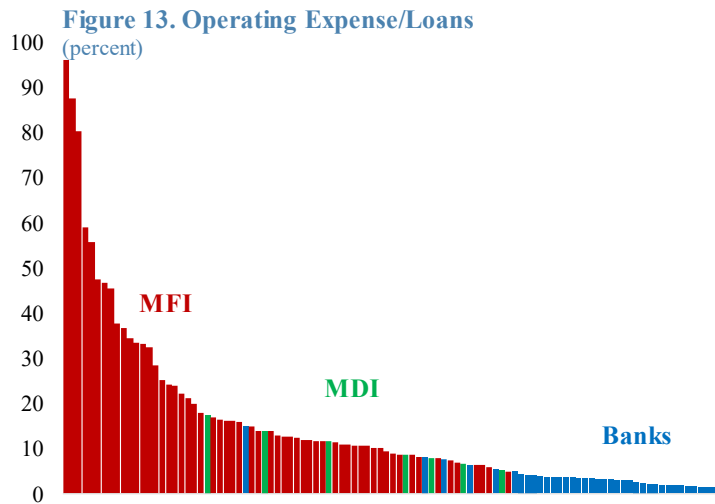
Source: National Bank of Cambodia customers for repayment collections.

\footnotetext{
${ }^{12}$ Rental expenses constitute about $11 \%$ of the overall operation expenses
} 
Compared to commercial banks, the operation cost is about 3 times higher for MDIs, and 6.5 times for MFIs. For instance, disbursing a 500 USD loans in rural areas costs about 15 percent of total loans including staff time, transportation, and communication. For such microfinance loans, although technology has helped keep costs as low as possible, it cannot yet replace the last-mile human contact. Although labor intensive, this practice ensures close relationship with the customers and allow prompt actions if needed. Overhead cost alone account for about 8 percent of loan costs. In addition, having a physical presence in areas where they operate is also important to promote access to finance. Microfinance institutions' branches account for $62 \%$ of total financial institutions' branches in the country.

\section{Funding costs}

Microfinance institutions' funding structure is largely different from and higher than those of banks. Although the seven MDIs can take deposits, 69 MFIs cannot take deposits and thus rely more on foreign and domestic borrowings ${ }^{13}$ (Figure 14). For MDIs, despite domestic deposit taking, more than $80 \%$ of funding are from foreign investors (Figure 15). Deposit rate are usually higher in MDIs than in banks which explains high interest expense by MDIs. MDIs are perceived by to be riskier than banks. Higher deposit rates at MDIs also reflect MDIs effort to attract deposits. Fixed-term deposit rates at MDIs is 7.5 percent $^{14}$, compared to 4.4 percent at commercial banks (Figure 16). The interest rate for foreign borrowing by microfinance institutions ranges between 2.5 and 5 percent, depending on currencies and borrowers (Figure 17). For MFIs (non-deposit taking), the costs of funding vary significantly because some MFIs financing is partly subsidized by donors, charities and/or social-oriented investors at lower market rates.

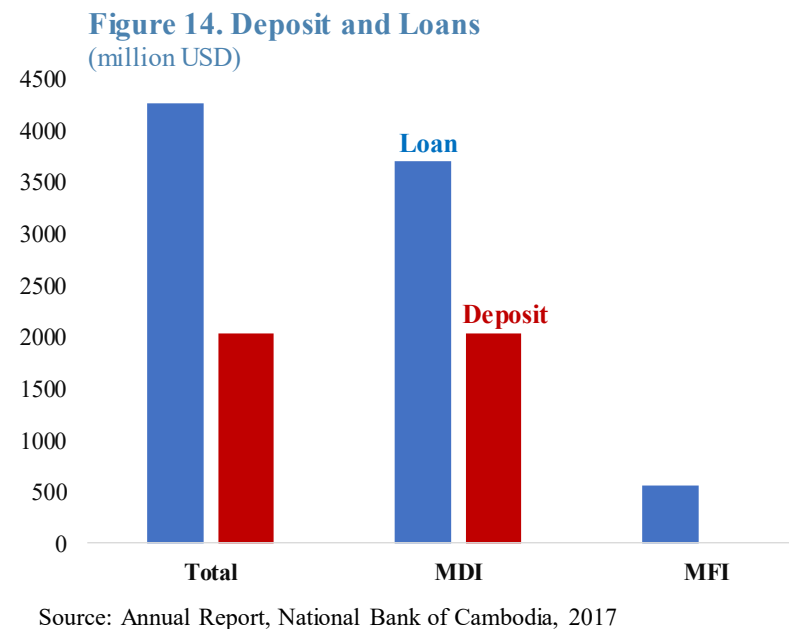

Source: Annual Report, National Bank of Cambodia, 2017
Figure 15. Composition of MDIs' Funding

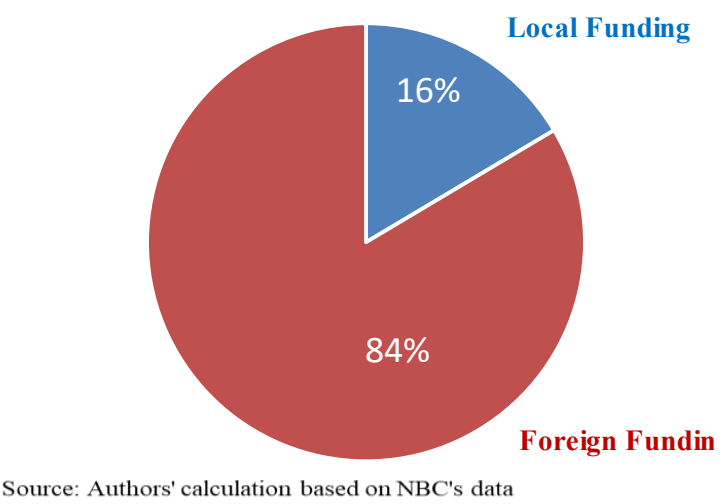

${ }^{13}$ Only a handful of MFIs can access foreign funding. The rest make use of borrowings from shareholders and their family and friends.

${ }^{14}$ For MDIs, in 2017, the one-year fixed term deposit at MFI is about 7 percent. 

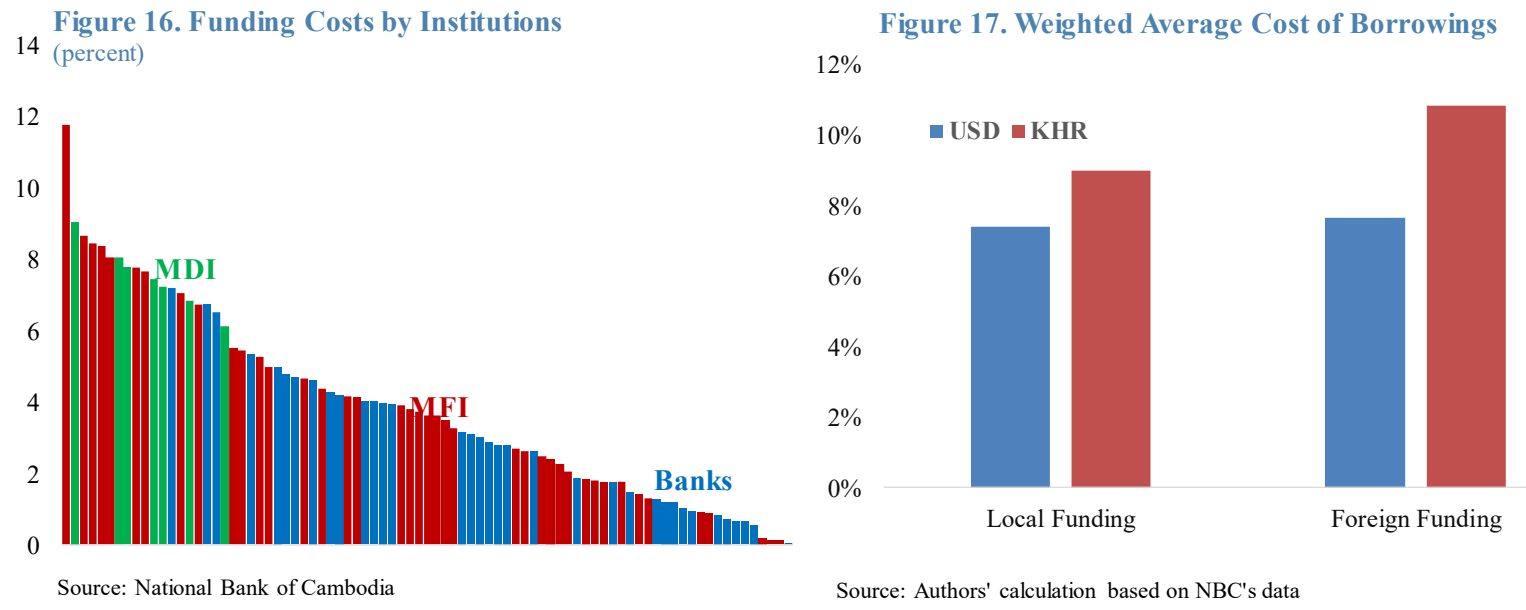

Concerns on Microfinance: A Mission Drift?

Amid fast growing microfinance sector and despite significant decline in interest rates, there have been concerns of over-indebtedness and still relatively high interest rate, which could undermine the healthy development of the sector. The success of the microfinance sector in 2000 s both in fulfilling its social mission and in profitability attracted many investors both development funds and private funds into the industry, tripling the number of MFIs operating in the country. It is worth mentioning that 7 MDIs in Cambodia are "SMART campaign certified"15, complying with consumer protection principles set by global microfinance industry (Centre for Financial Inclusion, the Smart Campaign).

However, fierce competition amongst players may have led to a drift in mission. Although there are no official records, there are reports on social media and news outlet about rural borrowers falling prey to unethical lending and practice. Instances of multiple-borrowings, high interest rate charged, migration from the village due to inability to repay debt or foreclosure of a live-in property were amongst the cases cited. In early 2017 before the cap, on average, there were eight microfinance institutions operating in a village ${ }^{16}$. Despite the lack of income data and related DTI ratios to measure the level of household indebtedness, some measures suggest significant increase in household level of indebtedness. Estimates based on consumption data and household survey suggest a significant increase in household indebtedness with the debt to consumption ratio increasing from 24 percent in 2010 to around 50-80 percent in 2016 depending on income levels (World Bank, 2018). According to Microfinance Index for Market Outreach and Saturation (Mimosa, 2015), Cambodia is

15 "SMART campaign" is a client protection certificate issued by the SMART campaign organization. www.smartcampaign.org

16 The estimate is based on data from NBC Quarterly 2017. 
among the most saturated credit markets in the world given the rapid credit growth (e.g., 46 percent per year during 2011-2014). The level of credit saturation, nonetheless, varies by provinces. Survey by Mimosa (2015) points to many cases of multi-borrowings and that market vendors are approached 2-3 times in the past one month with loan offers from different institutions. About 36 percent had more than one loan: 25 percent of borrowers had two loans, nine percent had three loans, and two percent had more than three loans (Credit Bureau Cambodia (CBC), 2016) ${ }^{17}$. Moreover, according to Cambodia Microfinance Association (CMA) statistic, clients borrowing from one institution to pay off debt at another has become common practice, with the period of clients waiting to refinance old debt become shorter ${ }^{18}$.

Against this background, some also claimed that the microfinance problem shifted from "limited access" to finance to "too much debt" among the poor who have loans from several microfinance institutions. At the same time, despite the fierce competition, there are still concerns on the relatively higher interest rates charged by microfinance institutions. The average interest rate before the interest rate cap was between 20-36 percent, while the interest rate for high risk loan can be higher than 50\% per year (Figure 18 and 19).

Moreover, there have been concerns on the regulatory arbitrage among types of lenders, especially among microfinance institutions and pawnshop. Pawnshops are licensed by the ministry of Economy and Finance and are not subject to the interest rate ceiling set by the NBC. Minimum capital requirement for pawnshop is much lower than that for microfinance institutions. In addition, there have been increasing concern over the emergence of unregistered or unlicensed entities engaging in microcredit activities. These lenders remain unregistered and unlicensed, with no reporting requirements to the $\mathrm{NBC}$ or other regulatory bodies.

\footnotetext{
${ }^{17}$ This survey figure could be underestimated as household relies on other family members for additional borrowing and credit bureau checks rarely include debt to others in the household.

${ }^{18}$ Usually a MFIs refinance a client of another institution after a period of regular payment to observe the behavior of the client before refinancing. Lately, the waiting time became less and less so much they are desperate to increase their customer base.
} 


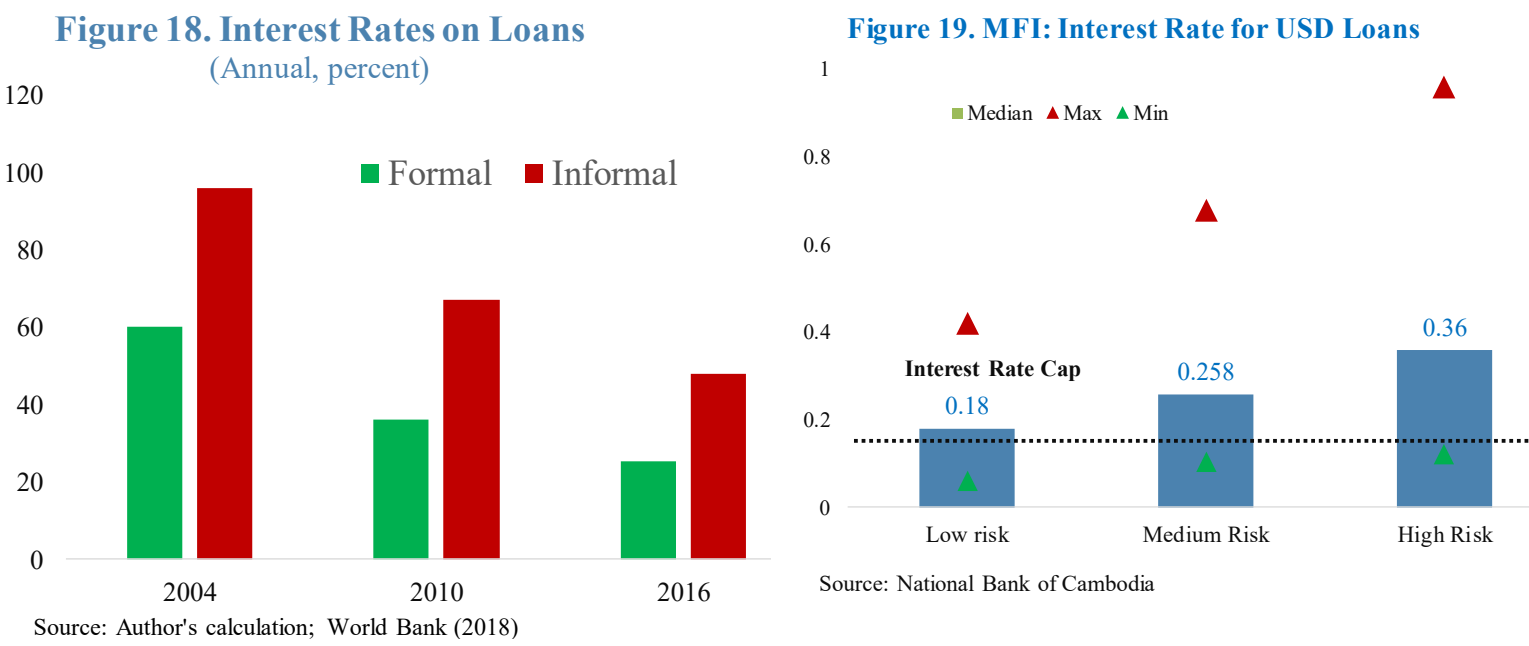

Deepening but not inclusive enough?

Despite rapid financial development, financial inclusion remains an important policy priority as only about $1 / 3$ of adult population in Cambodia has access to formal loans and saving accounts ${ }^{19}$ (World Bank Survey, 2017). Financial inclusion remains low compared to countries of similar income (Figure 20). Poor information on customers and weak contract enforcement as well as issues of multi ID documents result in high transaction costs and risk premium, especially for small loans. Fintech such as mobile phone services has been widespread but so far is mostly limited to remittance services. In 2016, about half of the borrowers have loans smaller than 500 USD (Figure 21). Another 20 percent have loans between 500 and 1000 USD. Most of this loan are for social loans, business loans, and personal finance. Social loans accounts for half of the loans below 500 USD and 20 percent of loans between 500-1000 USD. In 2018, after the cap, loans below 500 USD declined to about 30 percent of total loans (Figure 21).

\footnotetext{
${ }^{19}$ The national survey (Finscope survey 2016) which used a broader definition suggests a higher level of financial inclusion $(59 \%)$.
} 

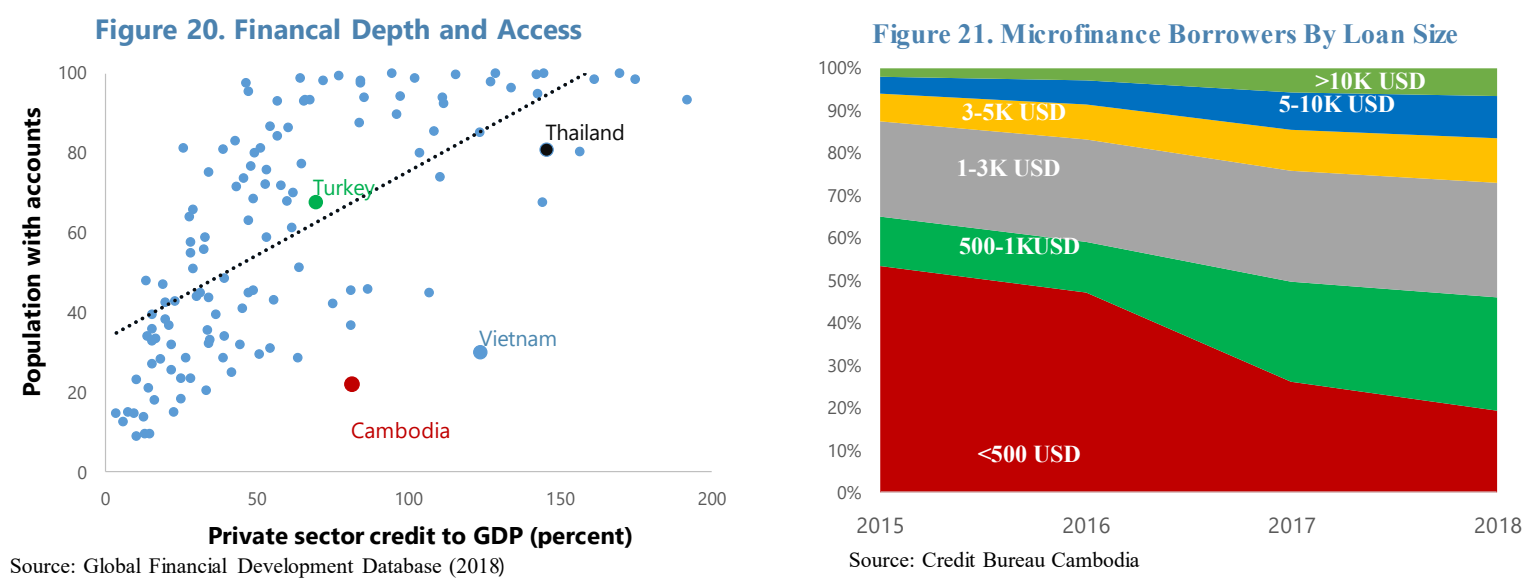

Against this backdrop, promoting financial inclusion while reducing over-indebtedness and preventing predatory lending in a fast-growing environment can be challenging. On the one hand, expanding services and improving outreach need to be further promoted to reach large segments of the population and to broaden the scope of savings mobilization and credit provision for key sectors such as agriculture. There is also a need to better understand how to extend access to financial services, especially for poor people in hard-to-reach areas where opportunities may be scarce and who might have limited knowledge about how to access available financial services. On the other hand, issues of over-indebtedness and irresponsible borrowing and lending, and a loss of lending discipline are at the heart of the concerns which triggered the introduction of interest rate cap by the government.

\section{The InTERest RATE CAP: PURPOSE AND DESIGN}

The interest rate ceiling of 18 percent was enforced on new or restructured loans of any maturity offered by microfinance institutions, rural credit institutions, and leasing companies from April 2017. In other words, the cap does not apply to loans contracted before April 2017. As stipulated in the regulation (Prakas in Appendix 4), the cap aims to protect consumers from excessive interest rates charged by microfinance institutions and to effectively promote the use of affordable loans (Article 2 of the Prakas) ${ }^{20}$. The regulation was driven by concerns that microfinance lending rates in Cambodia were excessive and that some financial institutions were engaging in predatory lending behavior.

The interest rate cap, issued by NBC, is characterized as follows:

- Scope of the cap: New loans offered by microfinance institutions, rural credit institutions, and leasing companies are subject to the interest rate ceiling. The cap is not applied to loans provided by commercial banks and other types of lenders such as pawnshops which are regulated by the Ministry of Finance. Figure 22 shows parts of financial system in which the new or restructured loans are subject to the interest rate cap.

\footnotetext{
${ }^{20}$ The regulation is attached in Appendix 4. See also interview by Director General of the National Bank of Cambodia in Sea-Globe Magazine. http://sea-globe.com/chea-serey/
} 
- Definition of the interest rate: The 18 percent interest rate cap refer to nominal interest rate and does not include other loan-related fees. In other words, microfinance institutions are not prohibited from charging non-interest fees such as commission fees or credit insurance fees.

- $\quad$ Binding: The cap is set at 18 percent per annum, which is below most interest rates charged by microfinance institutions, but largely above the rates charged by commercial banks (Figure 23). When the cap was introduced, commercial banks charged between 10-13 percent while microfinance charged 20-36 percent per year depending on loan risk and type of microfinance institutions. Moreover, although small loans tend to be costlier than larger loans, the new 18 percent cap is applied equally to all loan sizes.

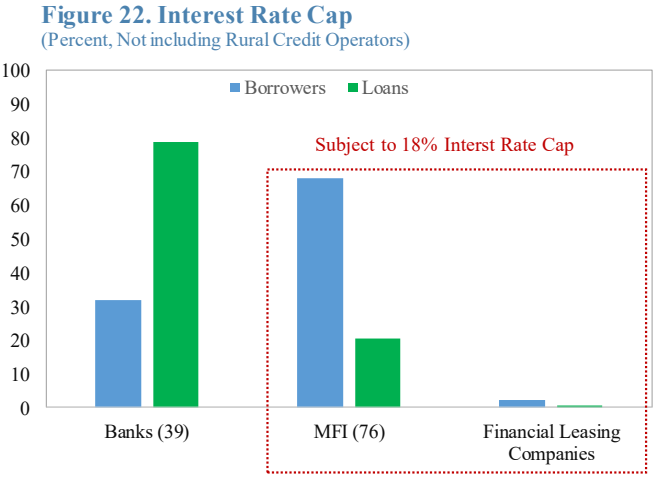

Source: National Bank of Cambodia Annual Report 2017

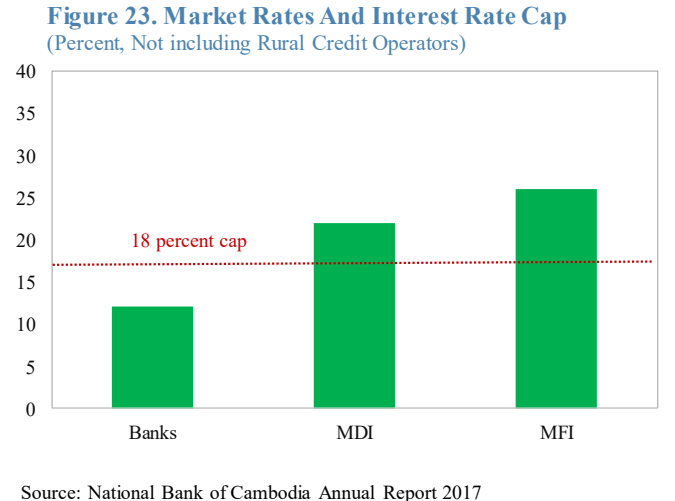

Source: National Bank of Cambodia Annual Report 2017

\section{IMPACT OF THE INTEREST RATE CAP IN CAMBODIA}

When an interest rate cap is imposed, financial institutions usually have three options: (i) comply with the cap by reducing operation costs, searching for lower funding costs, or/and compromising profit margin; (ii) increase loan-related fees such as commissions and credit insurance fees when they are not included in the calculation of interest rate cap; or (iii) convert to other types of institutions to avoid the scope of the interest rate cap (see Appendix A1 for cross-country experiences). In the first option, reducing operation costs often mean either improving operating efficiency or withdrawing services from costly rural areas, which can have negative effects on financial inclusion. In the second option, the interest rate cap is basically circumvented. The third option could lead to the emergence of informal lenders or financial institutions outside NBC's supervision, or a higher merger and acquisition among banks and microfinance institutions.

Overall, data suggests that all three options have taken place in Cambodia. Table 1 provides a summary of the change after the cap. Interest income declined reflecting that MFIs have complied with the nominal interest rate cap for new loans. This intention to comply is also observed through the increasing number of MDIs and MFIs looking for cheaper funding source by bringing in stronger shareholders from oversea. In 2017 and 2018, 4 MFIs were acquired by foreign banks or financial institutions who can access to cheap funding as well as bringing new services and best practices from their home countries. Bucking the trend over 
the past decade before the cap, number of borrowers declined by about 3 percent as MFIs withdrew from small borrowers who are relatively costly to serve. The decline, however, varies across financial institutions depending the ability to increase commission fees and to reduce operation costs. Moreover, MFIs appeared to have lowered their operation costs by leveraging mobile payment and change client base. Most MFIs opted for the second option as reflected in the increase in commission fees and increase in the loan size. In addition, our interview with some industry contacts suggest that that some MFIs set up separate pawnshops and book most of their credit operation there because less regulatory burden and don't have to comply with cap.

Table 1: MFI Response and Changes After the Cap

\begin{tabular}{|c|c|c|c|c|c|c|c|}
\hline & & & & & \multicolumn{3}{|c|}{ Change } \\
\hline & \multirow{2}{*}{$\begin{array}{r}\text { Before } \\
2016\end{array}$} & \multicolumn{3}{|c|}{ After the cap } & $2017-2016$ & $2018-2016$ & $2019-2016$ \\
\hline & & 2017 & 2018 & 2019 & & & \\
\hline Interest Income ( $\%$ of loans) & 20.8 & 16.9 & 15.0 & 14.2 & -3.9 & -5.8 & -6.6 \\
\hline Borrowers (thousands) & 1,825 & 1,775 & 1,873 & 2,109 & -51 & 48 & 284 \\
\hline Operation Expense ( $\%$ of loans) & 7.8 & 6.3 & 5.9 & 5.4 & -1.6 & -1.9 & -2.5 \\
\hline Return on Asset (\%) & 3.5 & 2.7 & 2.7 & 2.8 & -0.8 & -0.8 & -0.7 \\
\hline Fees ( $\%$ of loans) & 0.5 & 1.0 & 1.8 & 1.7 & 0.5 & 1.3 & 1.2 \\
\hline Average Loan Size (USD) & 1,718 & 2,406 & 2,899 & 3,416 & 687 & 1180 & 1697 \\
\hline Non-performing loans (\%) & 1.4 & 1.6 & 1.3 & 0.8 & 0.1 & -0.2 & -0.6 \\
\hline
\end{tabular}

Source: Authors' estimate, National Bank of Cambodia

\section{Increase in the number of institutions}

In 2018 after the cap was introduced, four new MFIs entered the market, bringing total number MFI to 80. At the same time, rural credit institutions increased from 170 to 310 . Regarding institutions outside the scope of the cap, the number of banks increased from 51 to 54 in 2017 and 56 in 2018; with one major microfinance institution converted to commercial bank.

In line with international experience, alternative lenders other than regulated has also emerged. Pawnshops, which largely involve in short-term lending, increased from 328 in 2016 to more than 500 in mid-2018. Loans provided by pawnshop has significantly increased from 38 million USD to 158 million USD by end 2020. This increase points to option 3 . There was also emergence of online and informal lenders with high interest rates, which prompted the NBC to issue a statement in July 2018 warning people about the danger of 
informal service providers. The NBC also extended its activities to raise awareness at local levels and took strong action including arrest against informal lenders ${ }^{21}$.

\section{Decline in nominal interest rates}

At industry level, microfinance sector's interest rate charge as a percent of total outstanding loans declined by about 3 percentage point from about 20.8 percent in 2016 to 17 percent in 2017 (Figure 25). This decline suggests the binding of the interest cap on microfinance interest rate for new and restructured loans. Microfinance institutions has complied with the interest rate cap by lowering deposit rates, and operation expenses.
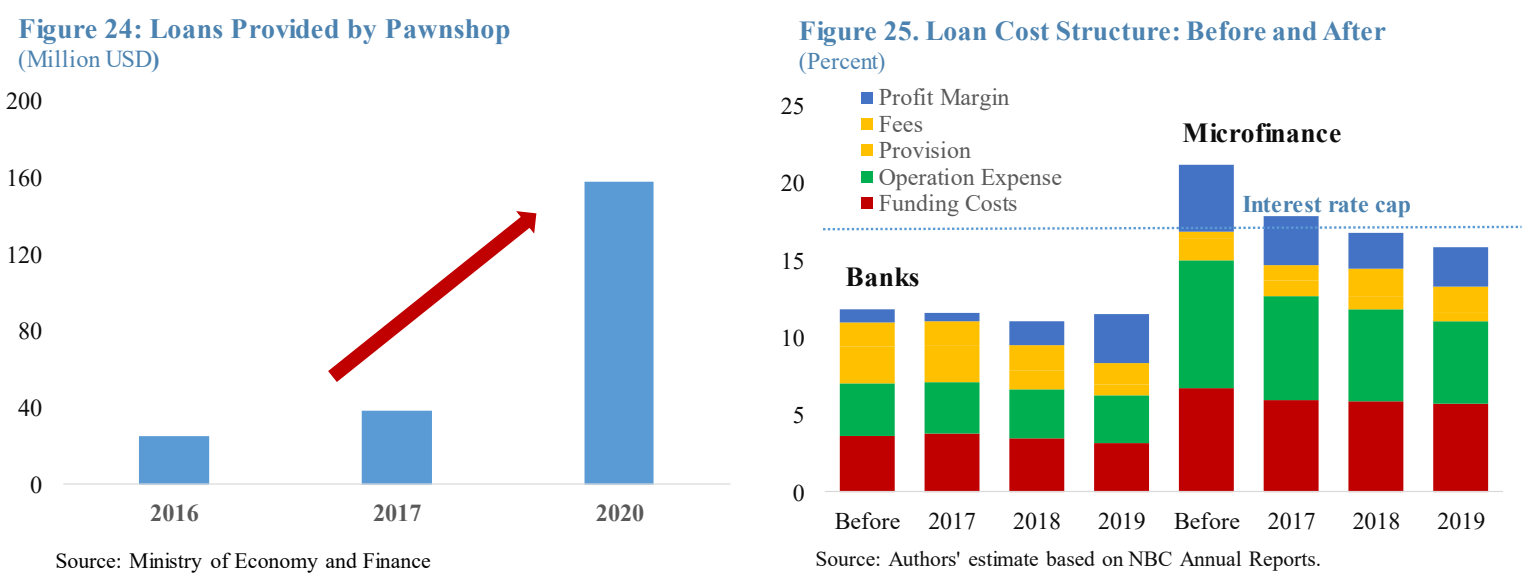

\section{Immediate decline and medium-term recovery in borrowers}

At end-2017, total number of borrowers declined by 3 percent since the introduction of the cap, bucking the upward trend over the past decade (Figure 26). By the first quarter of 2018 (one year after the cap), number of borrowers in nine rural villages (out of 197) declined for the first time while total loans in these villages increased (CBC Data 2018). ${ }^{22}$ This decline in borrower suggests a short-term negative impact of the cap on access to credit in formal sector. One major MDI was acquired by a foreign bank and drastically reduced small borrowers and shift the target to larger loans for urban customers.

Some 80 percent of this decline in total borrowers was driven by MDIs. But the change in number of borrowers varies by institutions (Figure 27). Borrowers of two major MDIs declined 14.5 percent and 27 percent respectively-combined, that is about 90,000 borrowers, or almost 3.6 percent of total borrowers. On the other hand, borrowers of other 3 MDIs increased while the rest are largely unchanged. This suggests that the impact on caps on

\footnotetext{
${ }^{21}$ Phnom Penh Post. "National Bank Head Calls on Cops to Bust 20 Illicit Lenders”, July 10, 2018. https://www.phnompenhpost.com/business/national-bank-head-calls-cops-bust-20-illicit-lenders

${ }^{22}$ Between 2011-2016, MFI borrowers have grown on average 13 percent a year.
} 
financial inclusion depended on the characteristics of microfinance institutions such as operation costs, funding costs, client base, and the ability to increase in commission fees to offset lower rates.

MFIs account for the rest of the decline. Half of the MFIs reduced the number of borrowers after the cap. The magnitude of the decline varies by MFIs with one MFI reducing borrowers by as many as 40,000 or about 83 percent of its borrowers before the cap.

Looking at the loan size, we observe that small loans declined significantly while larger loans increased. Specifically, loans below 500 USD declined significantly in 2017 while loans between 500-1000 USD increased. Among MDIs, loans below 500 USD declined by 49 percent in 2017 and another 31 percent in March 2018 (Figures 28 and 29). In contrast, the number of loans between 500-1000 USD increased by 100 percent in 2017. This largely reflects microfinance institutions' effort to increase loan size which tends to have lower interest rate and lower servicing costs. The decline was also partly caused by the change in fees of checking credit information by the CBC) in November 2017. The charges allow microfinance institutions to pay only one fees for checking multi-borrowers, which may have partly caused the drop in data on loans less than 500 USD. Among MFIs, loans below 500 USD decreased by 25 percent in 2017 while loans of 500-1000, 1000-3000 and 3000-5000 USD increased by about 31,46 , and 38 percent respectively.

The number of borrowers gradually increased and by the end-2019, the number of MFIs was 12 percent above the pre-cap number of borrowers. This suggests that the microfinance institutions have adjusted their operations and costs to comply with the interest rate cap while compete with other lenders.
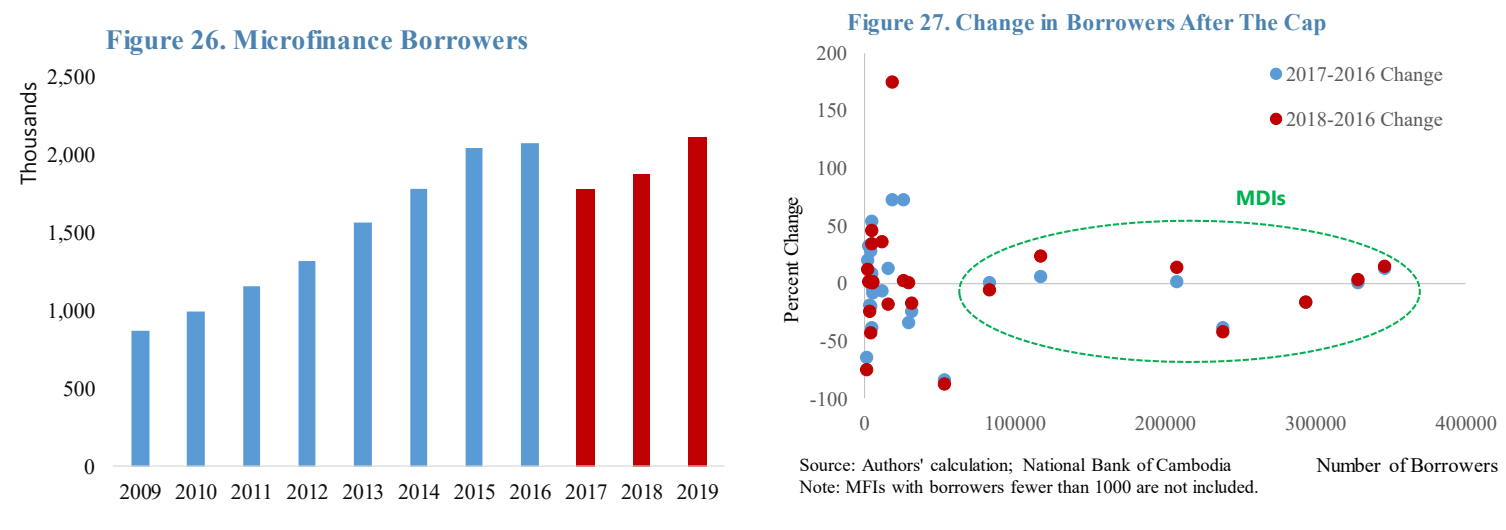

Source: National Bank of Cambodia 


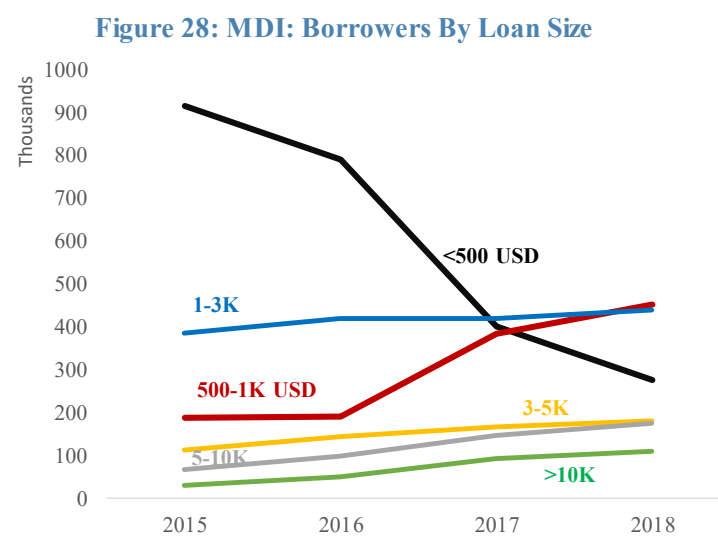

Source: Credit Bureau Cambodia

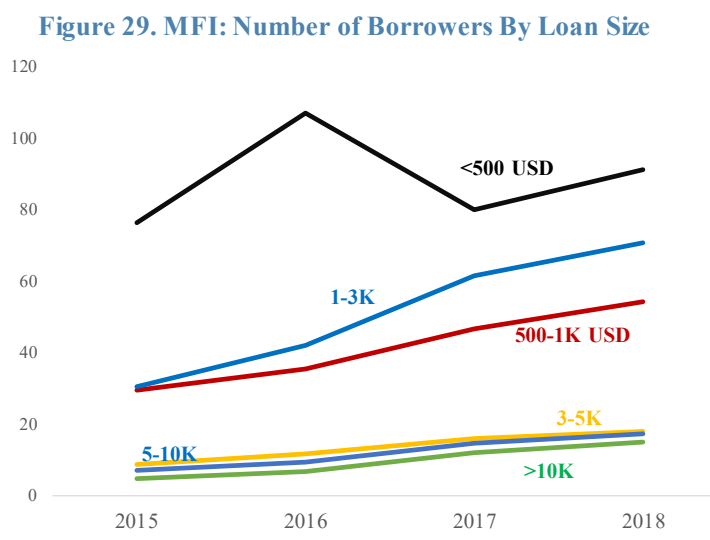

Source: Credit Bureau Cambodia

\section{Increase in Loan Supply and Loan Size}

The interest rate cap did not slow down the microcredit supply (Figure 30). After the cap, total credit provided by microfinance institutions continued to increase by 40 percent in 2017 compared to 23 percent in 2016 (Figure 31). Credit provided by MDIs increased by 37 percent in 2017 compared 22 percent in 2016. At the same time, credit provided by MFIs increased by 61 percent in 2017 compared to 33 percent yoy in 2016.

Average loan size increased significantly, exceeding the past five-year trend (Figure 32). Overall, the average loan size increased by 45 percent, higher than 23 percent in 2016 and 30 percent over the past five years. The increase in loan size after the cap is consistent with other countries' experience as financial institutions offset the impact on interest income by reducing segments that have high operation costs. As discussed in previous section, larger loans tend to be less costly to disburse and maintain compared to small loans and thus tend to have lower rates. The decline in small loans and the increase in average loan size suggest a credit rationing from small to large borrowers or higher debt for the same borrowers (Figure 33). This development is consistent with other countries' experience when interest rate cap is introduced (see Appendix A1). 


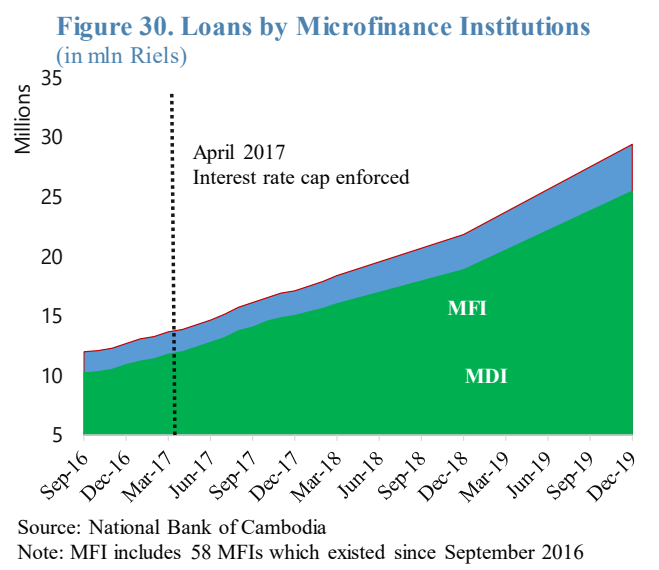

Figure 32. Growth in Average Loan Size (Percent, year on year)

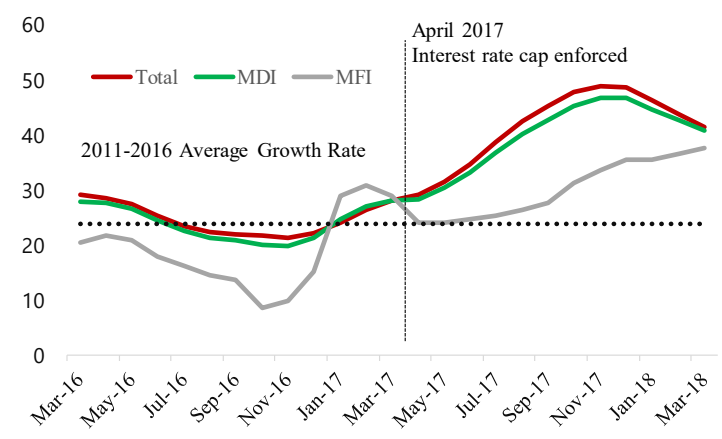

Source: National Bank of Cambodia

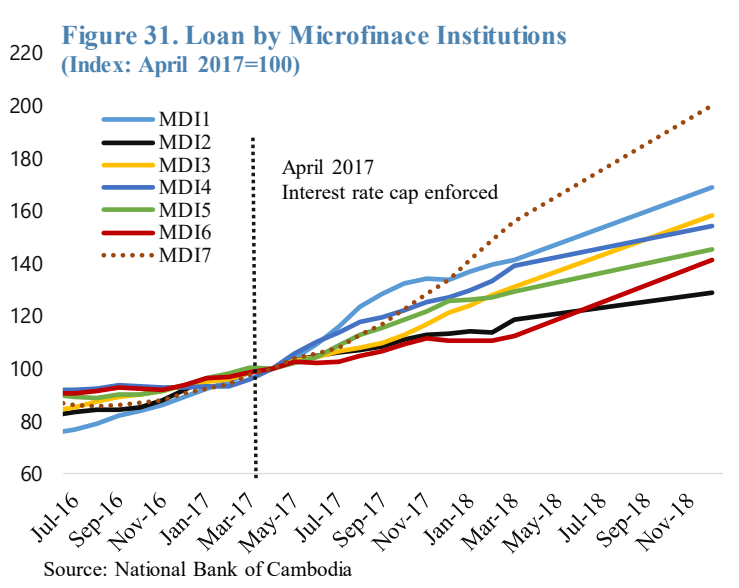

Figure 33. MDI: Share of Outstanding Loans

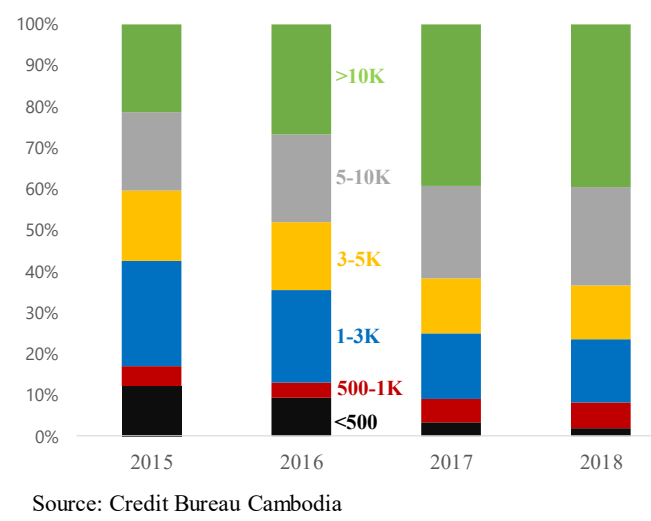

\section{Increase in Commission Fees}

Microfinance institutions appeared to offset the impact of the cap on profitability by charging other types of fees, especially commission fees. The total non-interest income of the microfinance institutions both as percentage of outstanding loans and in ratio to interest income has significantly increased after the cap (Figures 34 and 35). The commission fees charged by MDIs doubled and by MFIs tripled after the cap end-2017. The magnitude of the increase in non-interest fees vary by institutions. Among the seven MDIs, the non-interest fees increased by about 3 times in average, with some MDIs charging as much as 5 times higher. Meanwhile, interest income slightly decreased from 21 percent in 2016 to 17 percent of outstanding loans in 2017. In total, the interest and non-interest income of the microfinance industry (as percentage of outstanding loans) declined about 2 percentage point.

This development suggests largely a circumvention of the interest rate cap which does not include commission fees. This is consistent with cross-country experiences that financial institutions often turn to non-interest charges to maintain the profit and meet the cap 
requirement. The fees, together with limited financial literacy among the population, make it more complicated for borrowers to assess the overall costs of the loans.
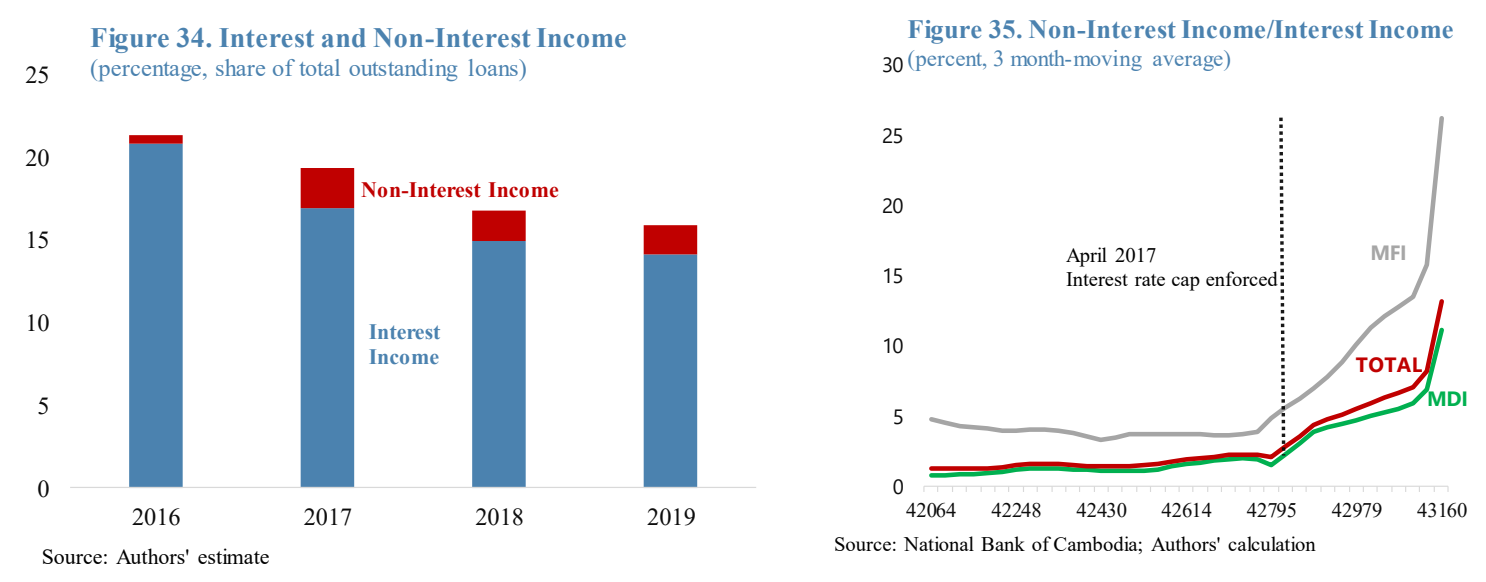

\section{EMPIRICAL ASSESSMENT}

The analysis focuses on the differential effects on credit, number of borrowers, average loan size, and non-interest fees among microfinance institutions in Cambodia.

We first run a simple regression based on monthly data with a dummy variable of interest rate cap to confirm the changes in key variables at microfinance institution level (Appendix 1 provide the details). The results are summarized in Table 2. At first look, we observe that after the cap was introduced, interest rate has declined, but microfinance institutions have charged higher fees and continue to increase loan size and increase average loan size. The change in number of borrowers and profitability, however, are ambiguous.

Table 2: Summary of The Impacts of Interest Rate Cap

\begin{tabular}{llll}
\hline & All & MDI & MFI \\
\hline Interest Rate & $(-)^{* * *}$ & $(-)^{* * *}$ & $(-)^{* * *}$ \\
Borrowers & $(+)^{*}$ & $(-)$ & $(+)^{*}$ \\
Loans & $(+)^{* * *}$ & $(+)^{* * *}$ & $(+)^{* * *}$ \\
Loan Size & $(+)^{* *}$ & $(+)^{* * *}$ & $(+)$ \\
Fees & $(+)^{* * *}$ & $(+)^{* * *}$ & $(+)^{* * *}$ \\
Profitability & $(-)$ & $(+)^{*}$ & $(-)$ \\
\hline Robust standard errors in parentheses: $* * * \mathrm{p}<0.01, * * \mathrm{p}<0.05, * \mathrm{p}<0.1$
\end{tabular}

Nonetheless, identifying the casual impact of interest rate cap is challenging here due to contemporaneous events such as the local and general elections in 2017 and 2018, as well as 
change in economic activities during the period. To address these issues, we turn to difference-in-difference approach, which captures the causal impact of a policy change by comparing the differences between the treated and control groups before and after the policy was implemented. Because the cap is applied to microfinance institutions, but not banks, the setting is good for the chosen approach to estimate the policy impact. Several banks and microfinance institutions such as MDIs compete on several fronts: geographic coverage (branches), loan types, and loan size.

In this case, bank is a control group and microfinance institution is a treatment group. We exclude specialized banks and banks with fewer than 500 clients from the sample, and for microfinance institutions, those with fewer than 500 clients as well.

The analysis uses the approach with the following specification:

$$
y=\beta_{0}+\beta_{1} \operatorname{cap}+\beta_{2} m f i+\beta_{3} \operatorname{cap} * m f i+\varepsilon
$$

where $y_{i t}$ is the outcome of interest, cap is the dummy variable to indicate the time when the interest rate cap was implemented. $\beta_{1}$ is the coefficient on a dummy that is equal to 0 prior to 2017 (before the cap) and 1 thereafter (after the cap). $m f i$ is the dummy variable for the microfinance institutions (both MFIs and MDIs) exposed to the interest rate cap (treatment group; it is equal to 0 for commercial banks as they are not subject to the interest rate cap (control group). We are interested in the significance levels of $\beta_{3}$ which is the coefficient for the difference-in-difference that captures the effect of the interest rate cap on key variables. We also include the funding costs and operation expenses in the regression as they affect microfinance financial institutions in providing loans and charging fees in response to the interest rate cap.

The study uses the supervisory data at end-2016 for the pre-cap period and 2017-2018 for post-cap period. Although the cap was enforced in April 2017, some microfinance institutions started to react to the speculation before the cap was imposed. The end-2016 helps filter out these effects. And for post-cap, we use an average data of 2017 and 2018 largely because, given the loan cycles (i.e. renewal of 6-12 month loans), some impact of the cap materialized only in 2018.

As shown in Table 3, the significant level of the interaction coefficient on fees confirm the widespread use of commission fees by microfinance institutions, to comply with the interest rate cap and offset the interest income loss. The findings on the increased commission fees is consistent with cross-country experiences discussed in Ferrari, Masseti, and Ren (2017).

The effects on the number of borrowers are not statistically significant and the coefficient has a negative sign. As discussed earlier, while some MDIs saw a significant reduction in borrowers, others increased the number of borrowers. This suggests that the impact has varied by institutions depending on operation costs, client base, and the ability to increase commission fees. 
Although the total loan and average loan size increased among many microfinance institutions, we cannot link the increase to the casual impact of the interest rate cap. Microfinance institutions respond differently as to whether to increase their loan size. Specifically, deposit-taking MDIs have tended to increase the loan size as they shift toward more quality customers in urban areas, whereas MFIs, by and large have not increased their loan size to meet the cap requirement. This may be partly explained by the fact that MFIs serves riskier clients and thus might face difficult to increase loan size.

The coefficient for profitability is not statistically significant, suggesting that profits among microfinance institutions are largely unchanged despite the cap. This is not surprising given the increased commission fees by microfinance institutions. In short, microfinance institutions still continue to lend to new borrowers while charge higher commission fees. In other words, microfinance institutions appeared to preserve their profitability while continue to extend loans to borrowers.

Table 3: Impact of Caps on Number of Borrowers and Fees

\begin{tabular}{|c|c|c|c|c|c|}
\hline & Non-Interest Fees & Number of Borrower & Total Loans & Average Loan Size & Profitability \\
\hline Microfinance dummy (mfi) & $\begin{array}{c}-14.49 * * * \\
(2.88)\end{array}$ & $\begin{array}{l}-0.52 \\
(0.48)\end{array}$ & $\begin{array}{c}-3.08^{* * * *} \\
(0.38)\end{array}$ & $\begin{array}{c}-2.55^{* * *} \\
(0.30)\end{array}$ & $\begin{array}{l}6.52 * * \\
(3.30)\end{array}$ \\
\hline Interest rate cap dummy (cap) & $\begin{array}{c}2.20 \\
(3.33)\end{array}$ & $\begin{array}{c}0.21 \\
(0.56)\end{array}$ & $\begin{array}{c}0.18 \\
(0.44)\end{array}$ & $\begin{array}{l}-0.03 \\
(0.35)\end{array}$ & $\begin{array}{c}1.25 \\
(3.80)\end{array}$ \\
\hline Interaction (cap*mfi) & $13.27 * * *$ & -0.07 & 0.30 & 0.39 & -1.08 \\
\hline & $(4.01)$ & $(0.67)$ & $(0.52)$ & $(0.42)$ & $(4.58)$ \\
\hline Funding costs & $\begin{array}{l}0.05^{*} \\
(0.03)\end{array}$ & $\begin{array}{l}-0.00 \\
(0.00)\end{array}$ & $\begin{array}{c}-0.02 * * * \\
(0.00)\end{array}$ & $\begin{array}{c}-0.01 * * * \\
(0.00)\end{array}$ & $\begin{array}{c}-0.86^{* * *} \\
(0.03)\end{array}$ \\
\hline Operation expense & $\begin{array}{c}0.37 \\
(0.34)\end{array}$ & $\begin{array}{c}0.48^{* * *} \\
(0.06)\end{array}$ & $\begin{array}{c}0.35^{* * *} \\
(0.04)\end{array}$ & $\begin{array}{c}-0.13^{* * *} \\
(0.04)\end{array}$ & $\begin{array}{l}-0.13 \\
(0.39)\end{array}$ \\
\hline Constant & $\begin{array}{c}16.85 * * * \\
(2.56)\end{array}$ & $\begin{array}{c}6.52^{* * * *} \\
(0.43)\end{array}$ & $\begin{array}{c}12.20 * * * \\
(0.34)\end{array}$ & $\begin{array}{c}5.68^{* * *} \\
(0.27)\end{array}$ & $\begin{array}{c}7.82 * * * \\
(2.93)\end{array}$ \\
\hline Observations & 168 & 168 & 168 & 168 & 168 \\
\hline R-squared & 0.29 & 0.32 & 0.58 & 0.55 & 0.84 \\
\hline
\end{tabular}

Standard errors in parentheses

$* * * \mathrm{p}<0.01,{ }^{* *} \mathrm{p}<0.05,{ }^{*} \mathrm{p}<0.1$

\section{CONCLUSIONS AND POLICY IMPLICATIONS}

In this paper we examined the short- and medium-term effects of the implementation of an interest rate cap on the microfinance sector of Cambodia. The findings suggest that although nominal interest rates are lower as intended by the cap, there are some signs of circumvention of the cap through enlarged non-interest fees and some short-term negative impact of the cap on small borrowers. Loan-related commission fees have increased across all microfinance institutions threefold. Nonetheless, the impact of the cap on the number of borrowers has varied across financial institutions depending on operation costs and segment of the clients they serve. Smaller MFIs appeared to have raised their commission fees rather than increasing their loan size, considering significant credit risks among small borrowers. In contrast, MDIs appear to increase both loan size and commission fees. 
The medium-term impact of the interest rate cap on financial inclusion subsided as MFIs and MDIs continue to increase loans and number of borrowers. They have managed to lower the funding costs, operation costs while continue to charge higher fees compared to the pre-cap period.

Going forward, if the interest rate cap is to be maintained to protect consumers from usury rates, the non-binding cap coupled with stronger consumer protection safeguard seems to be a better alternative.. The scope of implementation should also be clearly defined, particularly with regard to the loan characteristics (including size and availability and type of collaterals) and the calculation of related fees and charges in order to minimize unintended consequences. Enforcing the cap that is inconsistent with market conditions could reverse the financial inclusion efforts so far and create incentives for unregulated entities to emerge and grow. This would transfer the problem out of the domain of regulators.

Several policy options can help protect borrowers from excessive interest rate and limit the negative impact of the interest rate cap. These include enhancing the consumer protection framework, and fostering healthy competition and efficiency of the microfinance industry.

First, abusive and irresponsible lending practices such as lending without prudent regard for repayment capacity, deceptive terms, and unethical repossession techniques often cause more damage to poor borrowers than high interest rates per se. Further protecting consumer and preventing household indebtedness will require lender discipline and financial literacy among borrowers. This will also require strengthening consumer protection law enforcement. A solid regulatory framework is needed in order to avoid regulatory arbitrage amongst the different players such as microfinance institutions, pawnshop and informal money lenders. This is to ensure more transparency and healthy competition, which helps improve efficiency and lower interest rates.

Second, consumer education to make borrowers aware of the financial services and be able to make informed financial choice and to avoid usury is essential. Existing initiative on financial literacy such as "Let's Talk Money" campaign and the inclusion of financial literacy into the general education program are commendable efforts. However, to address the short-term needs of the industry prohibiting deceptive marketing techniques that hide the true costs of a financial transaction, transparent and responsible incentive scheme for credit officers and management should be considered. Requiring credit officers to go through training programs offered by the Banking and Financial Institute on ethical lending can also help ensure a standardized ethical approach is applied across the industry. Collaboration among the National Bank of Cambodia (NBC), CMA, CBC, and Association of Banks in Cambodia (ABC) should be further strengthened. Existing Banking Code of Conducts as well as the Sihanoukville Initiative are good attempts by the ABC and CMA to self-regulate, but the enforcement tools could be further enhanced and may need certain level of intervention from the NBC. More efforts should also be made by the industry in order to promote the usage of formal financial services and reducing the presence of informal lenders who do not fall within the regulatory perimeter of the NBC. 
Third, healthy competition among MDIs and further orderly consolidation of the MFIs may help improve efficiency by reducing overhead and operation costs. Further increasing capital requirement for microfinance institutions toward encouraging small ones to consolidate and improve their efficiency, can help reduce lending costs and irresponsible lending. Too much and too fast competition that comes with the rapid increase in the number of microfinance institutions often leads to irresponsible lending. Moreover, the operational efficiency should be also further achieved through lower costs of doing business and harnessing fintech. Existing mobile money transfer networks should be further capitalized to reduce the cost of loan disbursement and collection. Introducing tiered E-KYC and adopting alternative credit scoring and sharing among microfinance institutions can improve their credit underwriting and risk assessment and allow institutions to better price loans. Credit risk premia can also be reduced by more efficient loan foreclosure procedures and lower costs of debt collection. At the same time, risks related to Fintech such as cybercrime, transparency, and consumer protection need to be well managed in the process. 


\section{Reference}

Asian Development Bank, 2016. "Impact of Restrictions on Interest Rates in Microfinance", ADB Sustainable Development Working Paper Series.

Cambodia Credit Bureau, 2016. "CBA Annual Report 2016”, Phnom Penh, Cambodia.

CGAP, 2004, "Interest Rate Ceilings and Microfinance: the Story So far." Occasional Paper No.

9 (Washington: Consultative Group to Assist the Poor).

EIU 2013. "Global Microscope on the microfinance business environment". The Economist Intelligence Unit.

Federal Reserve Bank of San Francisco, 2007. “Japan's New Consumer Finance Law”, Asia Focus.

Ferrari, Aurora; Masetti Oliver, Ren Jiemin. 2018, "Interest Rate Caps: The Theory and The Practice”, Policy Research Working Paper 8398.

Heng, Dyna 2015. "Impact of the New Financial Services Law in Bolivia on Financial Stability and Inclusion", IMF Working Paper No.15/267.

Jafarov, Etibar; Maino, Rodolfo; and Pani Marco, 2019. "Financial Repression Is Knocking at the Door, Again. Should We Be Concerned?", IMF Working Paper, 19/211.

Mehnaz Safavian and Zia Bilal, 2018." The Impact of Interest Rate Caps on the Financial Sector: Evidence from Commercial Banks in Kenya”, Policy Research Working Paper WPS8393. Maimbo Samuel and Gallegos Claudia 2014. "Interest Rate Caps around the World: Still Popular, but a Blunt Instrument” Policy Research Working Paper 7070.

MIMOSA, 2015. "Microfinance Index of Market Outreach and Saturation: Cambodia".

National Bank of Cambodia, 2016. "Annual Supervision Report”, Phnom Penh, Cambodia.

National Bank of Cambodia, 2017. "Annual Supervision Report”, Phnom Penh, Cambodia.

World Bank, 2012, Global Financial Development Report 2013: Rethinking the Role of the State in Finance, Chapter 3 (Washington: World Bank).

World Bank, 2013, "Rethinking the role of state in Finance," Global Financial Development Report.

World Bank, 2014, "Financial Inclusion," Global Financial Development Report.

World Bank, 2017, "Microfinance and Household Welfare". Cambodia Policy Note, World Bank Group. 


\section{Appendix 1: Cross-country experience: Interest rate caps and financial inclusion}

Cross-country evidence on the effectiveness of interest rate caps is mixed (Maimbo and Gallegos 2014). In theory, interest rate caps can help reduce the cost of borrowing for consumers and are often used by governments and tends to be a politically popular tool to protect unsophisticated borrowers from predatory lending. However, the real economic impact depends on three factors: (i) how banks adjust supply and composition of loans in reaction to the cap; (ii) how consumers adjust their demand for credit; and (iii) whether and how much the cap is set below the current market interest rate.

Although more than 70 countries worldwide have enacted interest rate caps to some degree, they vary in scope and forms (Ferrari, Masetti, and Ren, 2018). Interest rate caps vary substantially regarding what they cover, how they work, and how interest rates are defined. For instance, if the primary rationale of the cap is to protect consumers, caps are usually set at levels that only limit extreme pricing but leave the core market with minimal implications. In contrast, if the objective of interest rate caps is to achieve certain socio-economic goals, such as lower overall cost of credit, ceilings are set at "binding levels" intended to influence the market outcome ${ }^{23}$. The binding constraints can alter the structure of the financial market if effectively enforced (Mehnaz and Bilal, 2018). Recent examples include Bolivia, Zambia and Kenya where caps were fixed substantially below prevailing average lending rates (Heng 2015). These variations make it difficult to make cross-country assessment on the impact of interest rate caps.

However, despite their good intentions, international experience predominantly points to negative impact. These effects include reduction of credit availability, increase in costs for low-income borrowers, withdrawal of financial services from the poor, and loss of transparency of financial product. In many African countries, the cap lead to an increase in illegal lending outside the regulation, an increase in additional fees and commissions and a decrease in product diversity (Maimbo and Collegos, 2014). Jafarov et al. (2019) show that over time countries would be better-off without financial repression, namely governmentmandated limits on the interest rates that financial institutions can apply to their deposits and loans.

\footnotetext{
${ }^{23}$ There are two types of interest rate caps. First is the absolute cap which refers to the fixed nominal rate that may not be exceeded. In some countries, there are even multiple and different caps based on the size, or type of loans, the socio-economic characteristics of the borrowers, or the industry. Second is the relative cap which means the maximum level of the allowed interest rate depends on the level of a benchmark rate. The cap is then usually either defined as a certain spread over the benchmark such as policy rate or average market rate. Different from the absolute caps, relative caps vary over time based on the movement of the benchmark rate.
} 
Overall, experience from other countries point to the following effects, which serve as useful angles to examine the impact in Cambodia in the next section. As discussed in Ferrari et al. (2018), these effects are:

- $\quad$ Caps set above the market rate do not seems to affect the market and can help limit predatory practice. Caps set above market rates affect only extreme pricing with little impact on the overall market. If interest rate caps include regulations on non-interest fees, caps can potentially help remove predatory lenders.

- $\quad$ Caps are often circumvented by the use of non-interest fees and commissions. To maintain the profit and meet the cap requirement, financial institutions often turn to non-interest charges which make it more complicated for borrowers to assess the overall costs of the loans. Specifically, when interest rate is not clearly defined, the cap tends to be circumvented with financial institutions charging non-interest fees such as commission fees for loans.

- $\quad$ Caps set well below market rate can discourage financial institutions to lend. The impact on the credit supply reduction depends on the scope of the cap. Blanket caps can lead a large decline of unsecured and small loans, as well as in credit to SMEs and riskier sectors. Moreover, loan size tends to increase, suggesting a credit rationing from small to large borrowers and potentially concentration risks.

In Japan, the introduction of interest rate cap in 2006 led to reduction of credit supply, drop in acceptance of loans application and emergence of illegal lending (FRB San Francisco, 2007). Similarly, in India, the interest rate caps in 2011 led to a slowdown in borrowing and lowered formal financial access (ADB, 2016). Recently in Kenya, the interest rate caps led to a significant decline in aggregate lending, an increase in nonperforming loans, and a lending shift away from small and medium enterprise toward safer corporate clients (Mehnaz and Bilal, 2018). In Nicaragua, the application of an interest ceiling caused microfinance institutions to reduce lending and withdraw from rural areas due to high operation costs and risks (CGAP, 2004). They also responded by added fees and other charges to cover their costs, since these were not capped.

In South Africa, several financial institutions circumvented the caps by charging credit life insurance and other service fees, which reduced the transparency of the total costs of loans (Mehnaz and Bilal 2018). Similarly, in Armenia, the lack of clarity on how to calculate the interest rate led banks and microfinance institutions to impose fees and commissions, reducing transparency but still having payment burden on borrows.

In summary, these studies suggest that cap may create incentives for unregulated entities to emerge and grow which merely transfers the problem out of the domain of regulator which set the ceiling. Cap is often difficult to enforce but can often lead to evasion through alternating products or charges. It can also stifle credit product innovation and finer market segmentation by confining the acceptable range of rates and products. 


\section{Appendix 2: Structural break of key variables among MDIs and MFIs.}

We first confirmed the change in key variables of interest at financial institution level using the following specification with robust standard error:

$$
y_{i t}=\propto_{i}+\beta_{1} \text { Post }_{\text {April2017 }}+\varepsilon_{i t}
$$

where $y_{i t}$ is the outcome of interest in the sector at month $\mathrm{t}, \propto_{i}$ is the dummy for institutions (i.e. fixed effect for banks, MDIs, and MFIs) which controls for all time-invariant change, $\beta_{1}$ is the coefficient on a dummy that is equal to 0 for all months prior to April 2017 and equal to 1 for April 2017 and thereafter. We are interested in the significance levels of the coefficient $\boldsymbol{\beta}_{\mathbf{1}}$ which represents the average change in outcome y in the post-April 2017 period.

Table A1 summarizes the effects of caps on MDIs. First, the effects on number of borrowers are statistically insignificant although the coefficient has negative sign. As discussed in the previous section, while some MDIs saw significant reduction in borrowers, others MDIs increased the number of borrowers. This again suggests that the impact varies by institutions depending on operation costs, client base, and the ability to increase commission fees. Second, the effect of caps on average loan size is positive and statistically significant, suggesting that MDIs responded to the interest rate cap by increasing loan size to meet the cap requirement. Third, the effect on commission fees is positive and statistically significant, confirming that MDIs responded to the cap by increasing commission fees. Fourth, the coefficient for profitability is positive and statistically significant, suggesting that MDIs' profits actually increased despite the cap. This is not surprising given the increased loan size and commission fees, and reduction of small borrowers who are relatively costlier to serve.

Table A1: MDIs' Response to Interest Rate Cap

\begin{tabular}{lcccccc}
\hline & Borrower & Loans & Loan Size & Fees & Fees/Interest Income & ROA \\
\hline \multirow{2}{*}{ Post April 2017 } & & & & & & \\
& -0.06 & $0.41^{* * *}$ & $0.46^{* * *}$ & $1.95^{* * *}$ & $0.08^{* * *}$ & $0.01^{* * *}$ \\
Constant & $(0.08)$ & $(0.03)$ & $(0.06)$ & $(0.34)$ & $(0.02)$ & $(0.00)$ \\
& $12.20 * * *$ & $3.23^{* * *}$ & $-6.67 * * *$ & $7.11^{* * *}$ & $0.01^{* *}$ & $0.02^{* * *}$ \\
& $(0.02)$ & $(0.01)$ & $(0.02)$ & $(0.11)$ & $(0.01)$ & $(0.00)$ \\
\hline Observations & 288 & 288 & 288 & 250 & 288 & 288 \\
R-squared & 0.057 & 0.585 & 0.649 & 0.466 & 0.452 & 0.140 \\
Institutions & 8 & 8 & 8 & 8 & 8 & 8 \\
\hline Robust & & & & & 8 \\
\hline
\end{tabular}

Robust standard errors in parentheses: ${ }^{* * *} \mathrm{p}<0.01,{ }^{* *} \mathrm{p}<0.05,{ }^{*} \mathrm{p}<0.1$

Table A2 shows the effects of caps on MFIs. Highlighted here is that different from the case in MDIs, the effects on number of borrowers among MFIs are positive and significant at $10 \%$. This suggests that number of borrowers among MFIs had actually increased despite the cap. Second, the effect of caps on average loan size statistically significant, suggesting that 
MFIs, in contrast to MDIs, largely do not increase loan size to meet the cap requirement. Third, the effect on commission fees is positive and stronger than that in MDIs, confirming that MFIs also responded to the cap by increasing commission fees. Fourth, the coefficient for profitability is not statistically significant, suggesting that MFIs' profits are largely unchanged despite the cap. This is not surprising given the increased commission fees by MFIs. Overall, MFIs still continue to lend to new borrowers, but charger higher commission fees and largely do not increase loan size as in the case of MDIs. This is partly explained by the fact that MFI serves riskier clients and thus might face difficult to increase loan size.

Table A2: MFI' Response to Interest Rate Cap

\begin{tabular}{|c|c|c|c|c|c|c|}
\hline & Borrower & Loans & Loan Size & Fees & Fees/Interest Income & $\mathrm{ROA}$ \\
\hline Post April 2017 & $\begin{array}{c}0.24 * \\
(0.13)\end{array}$ & $\begin{array}{c}0.38 * * * \\
(0.13)\end{array}$ & $\begin{array}{c}0.15 \\
(0.09)\end{array}$ & $\begin{array}{c}1.18 * * * \\
(0.19)\end{array}$ & $\begin{array}{c}0.11 * * * \\
(0.03)\end{array}$ & $\begin{array}{l}-0.02 \\
(0.02)\end{array}$ \\
\hline Constant & $\begin{array}{c}6.71 * * * \\
(0.05)\end{array}$ & $\begin{array}{c}-1.30 * * * \\
(0.05)\end{array}$ & $\begin{array}{c}-5.71 * * * \\
(0.04)\end{array}$ & $\begin{array}{c}3.62^{* * *} \\
(0.08)\end{array}$ & $\begin{array}{c}0.06^{* * *} \\
(0.01)\end{array}$ & $\begin{array}{c}-0.02^{* * *} \\
(0.01)\end{array}$ \\
\hline Observations & 2,083 & 2,085 & 2,083 & 1,754 & 2,089 & 2,104 \\
\hline R-squared & 0.009 & 0.030 & 0.007 & 0.136 & 0.031 & 0.017 \\
\hline Institutions & 70 & 70 & 70 & 70 & 69 & 69 \\
\hline
\end{tabular}




\section{Appendix 3: Prudential regulation comparison between CBs and MDIs (MFIs)}

\begin{tabular}{|c|c|c|}
\hline Regulation & Banks & MDIs (MFIs) \\
\hline Licensing Registration & $\begin{array}{l}\text { Obligated for Licensing Registration regardless } \\
\text { (MFIs: Obliged if } \\
\text { - portfolio }>\$ 244 \mathrm{~K} \text { or borrowers }>1000 \\
\text { - saving }>\$ 24 \mathrm{~K} \text { or depositors }>100 \\
\text { (Otherwise, will be classified as MFOs)) }\end{array}$ & \\
\hline $\begin{array}{l}\text { Capital requirement (in } \\
\text { USD) }\end{array}$ & $\begin{array}{l}12.2 \mathrm{M} \text { if influential shareholder is BFI with a } \\
\text { rating of "Investment grade" } \\
\text { Otherwise, } 36.6 \mathrm{M}\end{array}$ & $\begin{array}{l}2.44 \mathrm{M} \text { (for other non-deposit taking MFIs: } \\
61 \mathrm{~K} \text { ) }\end{array}$ \\
\hline $\begin{array}{l}\text { Capital guarantee at } \\
\text { NBC }\end{array}$ & $10 \%$ of minimum capital (=capital requirement) & $\begin{array}{l}10 \% \text { of registered capital } \\
\text { (non-deposit taking MFIs: } 5 \% \text { of } \\
\text { registered capital) }\end{array}$ \\
\hline Net Worth (NW) & $\begin{array}{l}\text { NW }=\text { Tier } 1+\text { Tier } 2 \text { and } \\
\text { Tier } 2<\text { Tier } 1 \text { (or Tier } 2<50 \% \text { NW) }\end{array}$ & $\begin{array}{l}\text { NW }=\text { Tier } 1+\text { Subordinated debt } \\
: \text { capped at } 100 \% \text { Tier } 1\end{array}$ \\
\hline Solvency ratio & $15 \%$ (monthly reporting) & \\
\hline $\begin{array}{l}\text { Asset classification and } \\
\text { provisioning }\end{array}$ & $\begin{array}{l}\text { - past due }>90 \text { days }=>\text { substandard } \\
\text { - past due }>180 \text { days }=>\text { doubtful } \\
\text { - past due }>360 \text { days }=>\text { at loss } \\
\text { - Provisions for restructured loans }\end{array}$ & $\begin{array}{l}\text { - past due }>180 \text { days is doubtful: } 60 \text { days } \\
\text { if loan }<1 \text { year } \\
\text { - past due }>360 \text { days is at loss: } 90 \text { days if } \\
\text { loan }<1 \text { year } \\
\text { - NO provision for restructured loans }\end{array}$ \\
\hline Reserve requirements & $\begin{array}{l}\text { - } 8 \% \text { in KHR, on deposits and borrowings and } 12 \\
\% \text { for foreign currencies deposits and foreign } \\
\text { currencies borrowings } \\
\text { - Eligible assets at NBC averaged over } \\
\text { maintenance period } \\
\text { - Daily maintenance }>80 \% \text { of minimum } \\
\text { requirement } \\
\text { - in KHR, balance held at NBC for clearing } \\
\text { purposes included in eligible balance }\end{array}$ & $\begin{array}{l}\text { - } 8 \% \text { of deposits for both KHR and foreign } \\
\text { currencies } \\
\text { (non-deposit taking MFIs: NA) }\end{array}$ \\
\hline $\begin{array}{l}\text { Liquidity Coverage Ratio } \\
\text { (legislated Jan. 2016) }\end{array}$ & $\begin{array}{l}>60 \% \text { (as from Sept. } 2016 \text { ) } \\
\text { (non-deposit taking MFIs: NA) }\end{array}$ & \\
\hline Reporting big exposures & 50 biggest exposures (quarterly reporting) & No regulation \\
\hline $\begin{array}{l}\text { Large exposures }(>10 \% \\
\text { of Net Worth) }\end{array}$ & $\begin{array}{l}\text { Must be }<20 \% \text { of } \mathrm{NW} \text { (or }<35 \% \text { on accepted } \\
\text { request) } \\
\Sigma \text { large exposures }<300 \% \mathrm{NW}\end{array}$ & $\begin{array}{l}\text { - } 1 \text { client- }>\text { Must be }<2 \% \text { of NW } \\
\text { - group of related clients }-><3 \% \text { NW } \\
\text { - Deposit from } 1 \text { client }<3 \% \mathrm{NW} \\
\text { (non-deposit taking MFIs: Must be }<10 \% \\
\text { of NW) }\end{array}$ \\
\hline Fixed assets & $<30 \%$ of $\mathrm{NW}$ & No regulation \\
\hline $\begin{array}{l}\text { Prompt corrective action } \\
\text { (PCA) }\end{array}$ & \multicolumn{2}{|c|}{$\begin{array}{l}\text { based on solvency ratio } \\
\text { - Obligatory Capital restoration plan if Solvency ratio }<15 \% \\
\text { - special measures by NBC if Solvency ratio }<5 \%\end{array}$} \\
\hline $\begin{array}{l}\text { Net open position in } \\
\text { foreign currencies }\end{array}$ & \multicolumn{2}{|c|}{$\begin{array}{l}\text { Monthly reporting to NBC } \\
\text { limit of total open position }<20 \% \mathrm{NW}\end{array}$} \\
\hline Internal control & \multicolumn{2}{|l|}{ Regulation exists (MFIs: Same but not enforced) } \\
\hline $\begin{array}{l}\text { Governance in banks and } \\
\text { FIs }\end{array}$ & \multicolumn{2}{|l|}{ Regulation exists } \\
\hline
\end{tabular}




\section{Appendix 4: Regulation on the interest rate, March 2017}

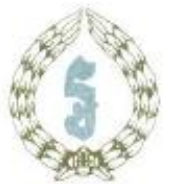

KINGDOM OF CAMBODIA

NATION RELIGION KING

NATIONAL BANK OF CAMBODIA

Number $\overline{B 7-017-109 P K}$

Unofficial Translation

PRAKAS

ON

INTEREST RATE CEILING ON LOAN

- With reference to the Constitution of the Kingdom of Cambodia;

- With reference to the Royal Decree NS/RKT/0515/417 of May 11, 2015 on the reappointment of His Excellency Chea Chanto as Governor General of the National Bank of Cambodia, equivalent to Senior Minister;

- With reference to the Royal Kram NS/RKM/0196/27 of January 26, 1996 promulgating the Law on Organization and Conduct of the National Bank of Cambodia;

- With reference to the Royal Kram NS/RKM/1206/036 of December 29, 2006 promulgating the Law on the Amendment of Article 14 and 57 of the Law on Organization and Conduct of the National Bank of Cambodia;

- With reference to the Royal Kram NS/RKM/1199/13 of November 18,1999 promulgating the Law on Banking and Financial Institutions;

- With reference to Prakas No B8-98-385 Prokor dated 20 July, 1998 on Organizational Structure of the National Bank of Cambodia and functions-duties of all departments of the National Bank of Cambodia;

- With reference to Prakas No B1-010-194 Prokor dated 26 November 2010 on the amendment of Article 3, Article 4, Article 5, Article 12 and Article 13 of Prakas on Organizational Structure of the National Bank of Cambodia and functions-duties of all departments of the National Bank of Cambodia;

- Pursuant to the recommendation made by the National Bank of Cambodia Management meeting on 13 March 2017.

Decides

Article 1.-

The purpose of this Prakas is to determine the interest rate ceiling on loan for banks and financial institutions under the National Bank of Cambodia's supervisory authority operating rural credit, hereinafter referred to as "Institution".

Article 2.-

The objective of this Prakas is to protect consumers from excessive interest rate charged by the institution and to effectively promote the use of affordable loan. 
Article 3.-

This Prakas is applicable to the microfinance deposit-taking institutions, microfinance institutions, and rural credit operators under the National Bank of Cambodia's supervisory authority.

Article 4.-

The institution shall set the interest not exceeding 18\% (eight teen percent) per annum for any maturity of loan.

Article 5.-

The interest rate ceiling as stated in the Article 4 above is effective for a new loan contract including restructured loan and refinancing with signature and/or finger print from $1^{\text {st }}$ April 2017.

Article 6.-

Failure to comply with this prakas may give rise to disciplinary sanctions as set forth in Article 52 of the Law on Banking and Financial Institutions.

Article 7.-

Any provision contrary to this prakas is hereby repealed.

Article 8.-

The General Secretary, the General Director of Central Banking, the General Director of Banking Supervision, the General Cashier, the General Inspector, Directors of all relevant Departments in the National Bank of Cambodia, and all Banks and Financial Institutions under the National Bank of Cambodia's supervisory authority shall strictly implement this Prakas.

Article 9.-

This Prakas shall take effect from this signing date.

Phnom Penh, 13 March 2017

The Governor

Signed and Sealed: Chea Chanto

To:

- As stated in article 8 "for implementation"

Ce:

Files - archives

- All members of the Board of Directors

- Council of Minister

"for information"

- Administrative Department of CM

"for publication in the National Gazette" 